\title{
Review
}

\section{The Role of Estradiol in Traumatic Brain Injury: Mechanism and Treatment Potential}

\author{
Erzsébet Kövesdi ${ }^{1}$, Edina Szabó-Meleg ${ }^{2}$ (D) and István M. Abrahám ${ }^{1, *}$ \\ 1 Molecular Neuroendocrinology Research Group, Institute of Physiology, Medical School, \\ Center for Neuroscience, Szentágothai Research Center, University of Pécs, H-7624 Pecs, Hungary; \\ kovesdi.erzsebet@pte.hu \\ 2 Department of Biophysics, Medical School, University of Pécs, H-7624 Pecs, Hungary \\ edina.meleg@aok.pte.hu \\ * Correspondence: istvan.abraham@aok.pte.hu; Tel.: +36-72-536-243 or +36-72-536-424
}

check for

updates

Citation: Kövesdi, E.; Szabó-Meleg, E.; Abrahám, I.M. The Role of Estradiol in Traumatic Brain Injury: Mechanism and Treatment Potential. Int. J. Mol. Sci. 2021, 22, 11. https://dx.doi. org/10.3390/ijms22010011

Received: 26 November 2020 Accepted: 18 December 2020 Published: 22 December 2020

Publisher's Note: MDPI stays neutral with regard to jurisdictional claims in published maps and institutional affiliations.

Copyright: () 2020 by the authors. Licensee MDPI, Basel, Switzerland. This article is an open access article distributed under the terms and conditions of the Creative Commons Attribution (CC BY) license (https: / / creativecommons.org/ licenses/by/4.0/).
Abstract: Patients surviving traumatic brain injury (TBI) face numerous neurological and neuropsychological problems significantly affecting their quality of life. Extensive studies over the past decades have investigated pharmacological treatment options in different animal models, targeting various pathological consequences of TBI. Sex and gender are known to influence the outcome of TBI in animal models and in patients, respectively. Apart from its well-known effects on reproduction, $17 \beta$-estradiol (E2) has a neuroprotective role in brain injury. Hence, in this review, we focus on the effect of E2 in TBI in humans and animals. First, we discuss the clinical classification and pathomechanism of TBI, the research in animal models, and the neuroprotective role of E2. Based on the results of animal studies and clinical trials, we discuss possible E2 targets from early to late events in the pathomechanism of TBI, including neuroinflammation and possible disturbances of the endocrine system. Finally, the potential relevance of selective estrogenic compounds in the treatment of TBI will be discussed.

Keywords: $17 \beta$-estradiol; traumatic brain injury; rodents; human; neuroprotection; treatment

\section{Introduction}

Traumatic brain injury (TBI) is defined as an alteration in brain function or any other evidence of brain pathology caused by an external force [1]. Importantly, TBI has become one of the leading causes of mortality and morbidity. However, the exact number of TBI cases per year is not known, due to many undiagnosed cases who do not receive medical care. The estimated incidence of hospitalized TBI patients is enormous, with an annual incidence of approximately 235/100,000 in the European Union [2], further associated with a cost of 33 billion euro [3].

Appropriate emergency medicine and intensive care reduce the number of deaths [4]; however, patients who survive TBI face numerous neurological and neuropsychological problems [5], such as cognitive, motor, and mental disturbances, which significantly affect their quality of life [6]. In most cases, the therapeutic TBI intervention involves surgical removal of hematomas and skull fractures, along with medical therapies to maintain proper cerebral perfusion and oxygenation of the brain tissue. In patients not needing surgery, the control of intracranial pressure (ICP) and cerebral perfusion pressure (CPP) are essential during the recovery phase in intensive care units. Since the primary injury itself cannot be treated, only secondary injury can be prevented or reduced; thus, experimental neuroprotective interventions focus mainly on the secondary injury. Several pharmacological treatment options have been tested in animal models, targeting the varied pathological consequences of TBI. More than 130 monotherapies seemed like promising neuroprotective agents in animal models [7] but failed in clinical trials. Based on the United States Government database (www.clinicaltrials.gov), 1308 clinical trials are still active or completed 
worldwide. From these trials, 867 addressed different therapeutic options but only seven dealt with clinical testing of neuroprotective agents. Therefore, to date, there is still no approved therapy for TBI $[8,9]$.

The outcome of TBI is sexually dimorphic in animal models and sex-dependent in patients with severe TBI. Several clinical studies have demonstrated that males have higher mortality rates and higher incidence of complications than females [10-12], suggesting that gonadal steroids such as $17 \beta$-estradiol (E2) play a critical role in the outcome of TBI. Animal studies have demonstrated the remarkable neuroprotective potential of E2 [13-16]. However, clinical trials have shown conflicting results regarding the effectiveness of female sexual hormones in TBI treatment $[17,18]$.

In recent years, several research groups demonstrated the effect of E2 as a possible therapeutic agent of TBI [19-22]. Accordingly, the aim of this review is to summarize the role and mechanism of action of E2 in TBI. First, we review the clinical aspects, pathomechanism of TBI, animal models, and E2-induced neuroprotective effects. Second, we discuss the possible mechanisms of E2 action targeting neuropathological events in TBI, such as disruption of the blood-brain barrier (BBB), mitochondrial dysfunction, free radicals, neuroinflammatory cascade, calpain activity, apoptotic cell death, and disturbance of the endocrine system, including hypothalamic pituitary-gonadal axis damage. Finally, based on the findings of preclinical rodent and human clinical studies, the relevance and potential clinical application of E2 and estrogenic compounds in the treatment of TBI will be summarized.

\section{TBI Classification}

Head injuries are classified into two major categories: primary and secondary injuries [23]. Based on the physical intervention, primary injuries can be further classified as penetrating (open-head) or nonpenetrating (closed-head). According to the neuroanatomical location, primary injuries can be focal or diffuse.

Focal injuries can be found in most forms of severe and moderate TBI. Contusion, hemorrhage, intracranial bleedings, including subarachnoid hemorrhage, and subdural hematoma are the typical forms of focal injury. While coup injuries occur at the side, the contrecoup are on the opposite side of the impact. Subarachnoid hemorrhage is the most common form of vascular injury in TBI [24]. Hemorrhage within the contusion area leads to the formation of local edema and ischemia and results in tissue destruction and neuronal necrosis [25]. Subdural hematomas are the result of ruptured veins due to rapid acceleration-deceleration forces during TBI $[26,27]$. Focal lesions are simple to identify by routine imaging techniques while promising blood biomarkers such as the glial fibrillary acidic protein (GFAP) and its breakdown products allow recognizing hemorrhagic lesions in very early stages, even in patients with relatively mild injury [28-30]. While these lesions mainly involve the frontal and temporal lobes, the subcortical white matter can also be affected in more severe forms of TBI. Hemorrhage within the contusion area leads to local edema formation and ischemia and results in tissue destruction and neuronal necrosis [25].

Diffuse injuries occur in a scattered form within the affected neuronal and vascular structures. Forms of diffuse injury include microvascular and axonal injuries [26]. Diffuse axonal injuries occur both in gray and white matter both in humans and animals in all severity ranges and forms of TBI, involving diffuse neuronal damage, microvascular change, axonal perturbation, and eventually, axon disconnection. Then, the distal, detached axonal projections undergo target deafferentation and synaptic loss with Wallerian degeneration [25].

\section{Pathomechanism of TBI}

Primary injuries are the result of external mechanical forces that produce irreversible tissue damage at the moment of the injury, lasting from microseconds to seconds (Figure 1). Importantly, in primary injuries, several neuropathological processes emerge: mechanical tissue destruction, cell and axonal stretching, blood-brain barrier (BBB) disrup- 
tion, synaptic loss, the failure of ATP-dependent glutamate transporters, and damage to blood vessels [31,32] (Figure 1). Excessive glutamate release after TBI is one of the key factors in TBI's pathomechanism. Elevated glutamate levels originate from damaged neurons and glia, from presynaptic vesicles of depolarized neurons, or from the damaged BBB [33] (Figure 1). The increased glutamate level correlates with injury severity and unfavorable outcomes $[34,35]$. Based on clinical studies, the glutamate level is highest immediately after injury, which can last one to two days post-TBI. Elevated glutamate levels lead to $\mathrm{N}$-methyl-D-aspartic acid (NMDA) and $\alpha$-amino-3-hydroxy5-methyl-4-isoxazole-propionic acid (AMPA) receptor activation [36] and the consequent accumulation of extracellular $\mathrm{K}^{+}$ and $\mathrm{Ca}^{2+}$ and $\mathrm{Na}^{+}$influx [37-39]. $\mathrm{Ca}^{2+}$ ions also enter cells via voltage-gated calcium channels (VGCCs) $[40,41]$ and the ionotropic P2X purinoceptor 7 (P2X7) [42]. Disturbed Ca ${ }^{2+}$ homeostasis triggers several parallel pathological events, such as mitochondrial dysfunction, oxidative stress, cerebral edema, and inflammatory cascades of the secondary injury (Figure 1). The secondary injury occurs from seconds to days from the time of the primary injury and influences the outcome and recovery [43,44]. Increased intracellular $\mathrm{Ca}^{2+}$ levels promote free-radical production and activate calcineurin, endonucleases, cytochrome $\mathrm{C}$, and calpain/caspase-mediated spectrin proteolysis, resulting in mitochondrial oxidative stress and apoptosis $[45,46]$. In addition, excess $\mathrm{Ca}^{2+}$ levels induce calpain and calcineurin activation $[47,48]$, which play a role in the formation of neurofibrillary tangles via cleavage-induced GSK-3 $\beta$ activation. This process leads to hyperphosphorylated tau [49], microtubule disruption, and tau accumulation [50,51].

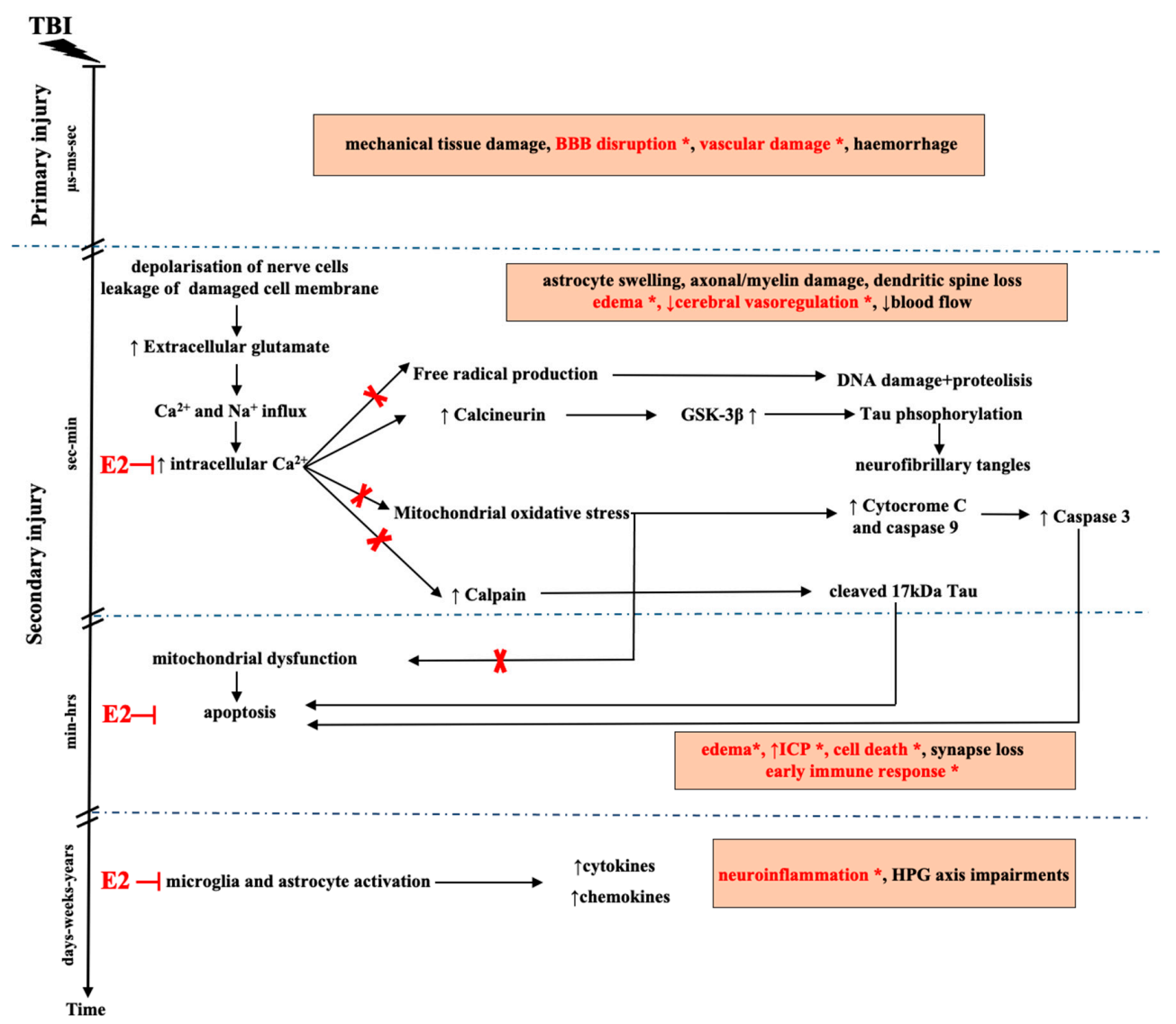

Figure 1. Timeline of events after the TBI and proposed neuroprotective effects of $17 \beta$ estradiol (E2). Red " $\mathrm{X}$ " or horizontal " $\mathrm{T}$ " letter and "*” with red letters depict blocked or reduced processes in the TBI pathomechanism after E2 administration. $\uparrow$ : increased, $\downarrow$ : decreased. Abbreviations: BBB: blood-brain barrier, GSK3 $\beta$ : glycogen synthase kinase 3 beta, HPG: hypothalamic-pituitary-gonadal, ICP: intracranial pressure, and TBI: traumatic brain injury. 
Neuronal mitochondria with high $\mathrm{Ca}^{2+}$ levels are targets for free radicals (Figure 1). The production of free radicals and the imbalance between oxidant and antioxidant factors after TBI promote the development of cerebral edema and increased ICP [52]. With the disrupted BBB, the increased ICP leads to immune cell entry, inducing oxidative damage and cell death through the elevated levels of various cytokines and chemokines [53]. Early neuroinflammatory responses begin a few hours after TBI and last from weeks to months due to microglia activation [54] and the increased infiltration of neutrophils, macrophages, and gliosis around the affected brain area [55] (Figure 1).

\section{Animal Models of TBI}

Animal studies enable to explore the effect of TBI on various aspects like sex differences, age, onset of injury, type, and severity. However, modeling TBI is a major challenge for neuroscientists. To date, there is no comprehensive experimental model of TBI able to represent all aspects of the injury. Experimental focal injury models include the controlled cortical impact (CCI), midline/lateral fluid percussion injury (FPI), controlled concussion, and weight-drop models by Feeney [56] and Shohami [57]. The experimental diffuse injury models are Marmarou's impact acceleration model, diffuse brain injury, and inertial acceleration models [58]. The most frequently used animal models are the CCI, FPI, and Marmarou's model, which can mimic the pathophysiology and cognitive deficits of TBI [59]. CCI is used mostly in mouse experiments, while the other two are used in rats.

In the CCI model, the brain is impacted through a surgically exposed dura by a rapidly accelerated rod, which directly impacts the brain tissue [60]. The injury causes acute hematoma, BBB damage, cortical contusion, deep brain injury, and neurodegeneration around the impacted area [61]. The CCI model was further developed for closed skull injury, enabling the analysis of mild and repetitive TBI [61,62].

The FPI mimics human TBI without skull fracture [63], but it induces contusion, brain tissue stretching, subdural hematoma, and hemorrhage [64]. In the FPI, the intact dura is exposed through a needle (luer lock hub), and the injury is induced through this craniotomy by a pendulum striking the piston at the end of a tube filled with liquid. Based on the height of the pendulum, the injury severity can vary between mild and severe injuries. FPI primarily results in contusion, subdural hematoma, tissue shearing/stretching, and necrotic cell death. Secondary events include the activation of inflammatory glial cells and neuronal cell death [64]. It is interesting that the same device can be used for diffuse and mixed (focal and diffuse) injury: upper mild, moderate, and severe pressure impulses cause focal and diffuse injury, while lower mild pressure produces diffuse injury [65]. Based on the location of the craniotomy, there are two main FPI types: midline (MFP) and lateral (LFP). In MFP, the craniotomy is at the center of the sagittal suture, while, in the LFP, the skull window is performed $3.5 \mathrm{~mm}$ lateral to the midline [66]. LFP is an appropriate model for mimicking the histopathology and behavioral outcomes of TBI. In LFP, focal cortical contusion and the diffuse subcortical neuronal injury of the injured brain side are minimally transferred to the noninjured contralateral side [67], so the contralateral side can serve as a control to evaluate the damage caused by the injury.

Marmarou's impact acceleration model mimics the human diffuse TBI resulting from falls or motor vehicle accidents [68]. A metal disc is used in this model, which is placed on the skull and protects the animal from bone fractures. Brain tissue deformation and injury severity can vary between mild and severe injuries based on the height of the falling impactor. The model can result in cell loss, diffuse axonal injury, astrogliosis, and hemorrhage [69].

Other weight-drop models include Feeney's, Shapira's, and Shohami's TBI models. In Feeney's model, the injury is caused by a falling weight through a craniotomy onto the intact dura. This injury causes cortical contusion [56,70], hemorrhage [71], and BBB damage [72,73]. In contrast to Marmarou's model, Shapira and Shohami's models use head fixation to avoid acceleration diffuse injury, such as that observed in Marmarou's model $[57,74]$. 


\section{E2 and Neuroprotection}

In the hypothalamo-pituitary-gonadal (HPG) axis, the central regulator of fertility, the hypothalamic gonadotropin-releasing hormone $(\mathrm{GnRH})$ neurons control the synthesis and pulsatile secretion of the luteinizing hormone $(\mathrm{LH})$ and follicle-stimulating hormone (FSH) [75] in the anterior lobe of the pituitary. The kisspeptin, neurokinin B, and dynorphin (KNDy) neurons of the arcuate nucleus co-expressing kisspeptin/neurokinin B/dynorphin are the main regulators of episodic $\mathrm{GnRH}$ release. In these neurons, neurokinin B initiates the pulse onset, kisspeptin drives GnRH secretion, and dynorphin terminates the pulse [76]. The released LH and FSH increase ovarian E2 synthesis and folliculogenesis during the estrus cycle [77]. In males, E2 is produced from testosterone via aromatase in adipocytes, bones, and the brain [78]. The E2 level in men is low, very similar to that in postmenopausal women [79].

In females, E2 has an important regulatory effect on the reproductive processes as a positive and negative feedback regulator $[80,81]$. E2 exerts a positive feedback action on GnRH neurons via kisspeptin neurons, inducing GnRH secretion, LH surge, and consequently ovulation. In male rodents, testosterone continuously inhibits the pulsatile function of GnRH neurons. In rodents, the pulsatile activity of GnRH neurons is controlled by a E2 negative feedback, with E2 inhibiting GnRH neurons for most of the estrus cycle [82].

In the brain, E2 originates from a variety of sources, including the gonads, local conversion of circulating androgen precursors via aromatase, and direct synthesis from cholesterol in neurons and the glia [83]. During brain injuries such as TBI, aromatase expression is induced in astrocytes [84-86], representing a mechanism of neuroplasticity activated for repair [87]. Brain steroidogenesis is independently regulated from peripheral steroidogenesis [88], because the enzymes responsible for E2 biosynthesis are present in the brain and expressed in both neurons and astrocytes [89,90].

E2 exerts its effects through two classical estrogen receptors (ERs), estrogen receptor alpha $(E R \alpha)$ and beta $(E R \beta)$ [91-93]. ERs are ligand-activated transcription factors in tissues that play a role in reproductive functions, and several tissues and organs, such as the brain, cardiovascular tissue, bone, immune cells, and liver express ER [94]. In the plasma membrane, ERs may be located in lipid rafts [95], allowing the direct interaction of ERs with different signaling pathways [96]. In the brain, ERs are expressed by neurons, microglia, astrocytes, oligodendrocytes, endothelial cells, and smooth muscle cells in blood vessels [97] and brain regions that play important roles in learning and memory processes, such as the amygdala, cerebral cortex, hippocampus, and basal forebrain [98]. The cellular effects of E2 occur through "classical" genomic and nonclassical signaling pathways. E2 effects via the "classical" pathway are slow and can last from hours to days. E2 binds to ER $\alpha$ or ER $\beta$ and triggers phosphorylation and dimerization of the ER-E2 complex, as well as the removal of regulatory receptor-associated proteins [99] and attachment of coactivators $[100,101]$. The dimerized complex translocates into the nucleus and binds to the estrogen response element (ERE), promoting the recruitment of specific coregulators that modulate the expression of target genes [102].

E2 exerts its rapid nonclassical effect on membrane receptors and intracellular signaling molecules. One of the targets of nonclassical E2 action is the classical ER associated with the membrane via scaffolding proteins such as caveolin-1 [96]. Importantly, E2 can bind to membrane receptors such as the $G$ protein-coupled estrogen receptor 1 (GPER1) [103]. Binding to cytoplasmic ER or GPER1, E2 induces ERE-independent gene transcription by activating different intracellular second messenger pathways, including mitogen-activated protein kinase (MAPK) [104], phosphatidylinositol 3-kinase (PI3K) [105,106], and protein kinases $A$ and $C$ [107]. The nonclassical effect of $E 2$ also involves the rapid phosphorylation of transcription factors such as the cAMP-responsive element-binding protein (CREB) [108], which initiates indirect gene transcription [109] and the regulation of several neurotrophic and neuroprotective factors, including hypoxia-inducible factor $1 \alpha$, brain-derived neurotrophic factor, vascular endothelial growth factor, transforming growth factor $\beta$, and glial derived neurotrophic factor [110]. In vitro studies in neuronal cultures demonstrated the 
neuroprotective effects of E2 against toxicity from serum deprivation [111,112], $\beta$-amyloid treatment $[113,114]$, and oxidative stress $[115,116]$. In vivo brain injury models have also confirmed the beneficial effects of E2 in different ischemia and neurodegenerative animal models after middle cerebral artery occlusion [117-119] and photothrombotic focal ischemia [120], as well as in Parkinson's [121,122], Alzheimer's disease [123,124], and multiple sclerosis [125] animal models. In general, the nonclassical pathway is responsible for the neuroprotective effect of E2 [123,124].

Animal experiments demonstrated the neuroprotective potential of E2 in TBI. Ovariectomized (OVX) rats have a larger contusion volume immediately postinjury compared to intact rats [126]. A negative correlation between the circulating E2 level and the size of brain damage is also known to exist: in metestrus, the E2 level is low, and the brain lesion size larger than in proestrus with high E2 levels [127]. In the CCI model, animals had increased neurological severity scores, brain infarction size, and lasting brain edema [128]. Regarding cognitive functions, impaired acquisition and the retrieval of spatial memory in the Morris water maze (MWM) and increased anxiety levels in the elevated plus maze (EPM) were observed [128]. However, a daily intraperitoneal E2 treatment for seven days before or after TBI significantly reduced the neurological severity scores, brain infarction volume, edema, and apoptosis in the hippocampus [128]. The E2 treatment also improved the acquisition and retrieval of spatial memory in MWM and reduced anxiety levels in the EPM test [128].

\section{Potential Targets of E2 Action in TBI}

Several experiments demonstrated the protective mechanism of E2 in TBI. In vivo animal experiments on female rats showed that TBI significantly decrease the ER $\beta$ mRNA level, while the ER $\alpha$ mRNA level does not change [129]. E2 administration restored the ER $\beta$ mRNA levels to normal and increased the ER $\alpha$ mRNA (18\%) and protein (35\%) levels in the brain [129], suggesting that ERs may play a role in the E2-induced protective mechanism in TBI. The target and mechanisms of action of E2 involve cellular structures such as the BBB and mitochondria and molecular processes including intracellular $\mathrm{Ca}^{2+}$ homeostasis, calpain/caspase activity, free radical production, and neuroinflammatory processes (Figure 1).

\subsection{E2 Effect on BBB and Mitochondria}

E2 treatment enhances the cerebral blood flow and reduces the brain edema size and the ICP [130] after TBI, suggesting that E2 is capable of dampening the vascular damage and BBB disruption in TBI (Figure 1). Indeed, E2 can exert its neuroprotective effect via vasodilation and the decrease of vascular inflammation in the BBB. E2 increases the expression of endothelial nitric oxide synthase (eNOS) via the classical and nonclassical estrogen pathways in vascular endothelial cells, leading to brain vasodilation [131,132]. In the rat model of Marmarou, E2, acting through ER $\alpha$ and ER $\beta$, decreased the edema and BBB disruption [133].

E2 also decreases inflammatory processes in endothelial cells by decreasing the expression of proinflammatory molecules such as e-selectin, intercellular adhesion molecule 1, and vascular cell adhesion molecule 1 [134] (Figure 1). Furthermore, E2 regulates the expression of tight junction proteins, playing an important role in the maintenance of the structure and integrity of the vascular endothelial membrane in capillaries $[135,136]$. These effects are mediated through the direct action of E2 on brain capillary endothelial cells [137] and indirectly through astrocytes and microglia.

Mitochondria-expressing ERs provide a platform for the neuroprotective effects of estrogens [138]. In vitro studies have demonstrated that E2 reduces mitochondrial dysfunction via the improvement of ATP production and moderation of intracellular $\mathrm{Ca}^{2+}$ levels during cellular stress to promote neuronal survival [139]. E2 maintains a normal level of ATP through increased oxidative phosphorylation and reduced ATPase activity and, thereby, increases the mitochondrial respiration efficiency and maintains normal 
mitochondrial functions. Furthermore, E2 increases the level of antiapoptotic proteins such as Bcl-2 and Bcl-xL to prevent the formation of a permeability transition pore (for review, see Nilsen et al. [140]).

\subsection{Inhibition of TBI-Induced Intracellular $\mathrm{Ca}^{2+}$ Increase after E2 Application}

Activity-induced presynaptic E2 production and release suggests that E2 may control the intracellular $\mathrm{Ca}^{2+}$ levels in neurons and astrocytes by regulating the neuronal excitability and preventing excitotoxicity and apoptosis [141,142] (Figure 1). Under pathological conditions, E2 is able to block the excessive increase of $\mathrm{Ca}^{2+}$ influx through L-type $\mathrm{Ca}^{2+}$ voltage-gated channels to protect motoneurons [143].

\subsection{Effect of E2 on the Calpain/Caspase Activity in TBI}

The modulation of apoptotic and necrotic cell death is a critical E2 cytoprotective mechanism, which may reduce the pathophysiological consequences of TBI [144,145]. There are two main mechanisms of neuronal cell death in brain injuries: apoptosis and necrosis [146]. Most apoptotic brain injuries can be either caspase-dependent or -independent. Mitochondria are essential for the activation of cell death signaling. Thus, the prevention of oxidative stress and the protection of normal mitochondrial functions result in decreased caspase activation and the inhibition of apoptosis [21]. In vitro studies demonstrated that $\mathrm{E} 2$ inhibits apoptosis in neurons exposed to glucose and oxygen deprivation [147], $\mathrm{H}_{2} \mathrm{O}_{2}$ [148,149], glutamate [143], $\beta$-amyloid [150], or neuroinflammatory molecules [151]. In a cortical contusion model (modified Feeney's weight-drop model) [56], E2 protected the cells in the peri-contusional zone against apoptosis through ER $\alpha$ upregulation and blocking caspase-3 activation via the classical genomic pathway [152] (Figure 1).

\subsection{Effect of E2 on Free Radical Production and Oxidative Stress after TBI}

The brain tissue is very sensitive to damage induced by free radicals [153,154]. Several mechanisms may contribute to the antioxidant activity of E2: transcriptionally activates antioxidant enzymes and proteins and inhibits reactive oxygen species (ROS) production through the activation of mitochondrial antioxidative enzymes $[155,156]$. For instance, E2 prevents the ROS production induced by the mitochondrial toxin 3-nitropropionic acid [155]. E2 also inhibits the production of superoxide [157] and activates superoxide dismutase in vascular tissue via the activation of extracellular signal-regulated kinase $1 / 2(E R K 1 / 2)$ [157] and regulates catalase and glutathione peroxidase [158,159]. Further, E2 attenuates the $\mathrm{H}_{2} \mathrm{O}_{2}$-induced dose- and time-dependent decreases in cellular ATP production [155,160] (Figure 1).

\subsection{E2 and Inflammation in TBI}

The anti-inflammatory role of E2 was demonstrated in in vivo experimental models of Alzheimer's disease [161], spinal cord injury [162], ischemic injury [163,164], and TBI $[86,165]$. In TBI, E2 treatment inhibits the production of inflammatory molecules such as tumor necrosis factor alpha, interleukin 1 beta, interleukin 6 , transforming growth factor beta 1 [166], and prostaglandin E2 [21,167]. Furthermore, E2 suppresses the cyclooxygenase-2 pathway in cerebral blood vessels, preventing the migration of microglia into the affected brain area [168] and inhibiting proinflammatory gene expression through the regulation of nuclear factor kappa B [169,170] (Figure 1).

The E2-induced anti-inflammation gradually declines with age. Animal experiments demonstrated that the physiological concentration of E2 has anti-inflammatory activity in the brain in young OVX mice but not in older female rodents [171,172]. Suzuki and coworkers found that this anti-inflammatory effect of E2 disappears during prolonged hypoestrogenicity in middle-aged [173] or in "reproductively senescent" [174,175] mice. 


\section{TBI and the Impairment of the HPG Axis}

Although the $\mathrm{m}$ part of our review focuses on the discussion of E2 action in TBI, clinical studies have demonstrated that TBI disturbs the HPG axis functions, including hormones such as E2.

Animal experiments demonstrated HPG axis abnormalities after TBI. LFP-induced injuries result in anterior pituitary dysfunction, impaired estrous cycle, and reduced E2 and LH levels one week after TBI [176]. The decreased hormonal levels could be explained by the altered sensitivity to GnRH or dysregulated GnRH release. Injured rats showed impaired spatial working memory and sensorimotor functions. Reduced synaptic density in the hippocampus was also found one week after TBI, which can be explained by the possible consequences of HPG axis impairment.

Impairment and disruption of the HPG axis are very common in patients with severe TBI [177-179]. For instance, injuries affecting the anterior pituitary or the hypothalamus lead to GnRH dysregulation, altered LH and FSH release, and consequent impairment of E2 production [180]. Neuropathological processes, together with HPG damage, are linked to poor outcomes as a long-term consequence of the injury [181-183]. Although E2 has neuroprotective actions in males and females [127,184-188], the supra-physiological level of sex hormones at the time of severe TBI are usually markers of mortality or unfavorable outcomes in both genders, especially in people around and above 50 years of age $[179,189]$. Increased cortisol (CORT) and E2 levels are observed in TBI but, also, after critical illnesses in older patients $[190,191]$. It is likely that older patients with severe TBI have enhanced stress responses with high CORT level [179]. In addition, as a response to stress, peripheral aromatization increases with age, resulting in higher E2 levels [192].

After TBI, most women experience disturbed menstrual periods or amenorrhea [193]. If these symptoms, including long-term hormone loss, appear during the reproductive age, it may affect their reproductive ability [194]. In postmenopausal women, increased age at the time of the injury, low hormonal levels, and TBI together can increase the risk of developing dementia $[195,196]$.

It is worth mentioning that trauma induces stress in TBI patients associated with high cortisol (CORT) levels. Importantly, increased CORT levels can lead to HPG axis dysfunction and disturbance in the menstrual cycle and induce hypogonadotropic hypogonadism and amenorrhea in women $[197,198]$. HPG dysfunction and amenorrhea have also been reported in patients several months after spinal cord injuries [199]. For instance, hypogonadotropic hypogonadism caused by a traumatic injury is a common observation after TBI [200]. In a study by Ranganathan et al., acute and long-term hormonal changes were analyzed in women after severe TBI [182]. They found that increased CORT levels after TBI physiological stress led to anovulation and HPG axis suppression [182]. In another study, similar observations were found in young women: higher injury severity was associated with higher CORT and lower FSH, LH, and E2 levels [201].

These results suggest that high CORT in TBI can induce impairments in HPG axis function, with a consequent reduction of endogenous E2 levels. Low E2 levels may also contribute to neuronal impairments after TBI. However, further experiments and clinical studies are required to elucidate the role and mechanism of TBI in HPG dysfunction.

\section{Potential Therapeutic Interventions with Estrogenic Compounds in TBI}

A long range of estrogen-containing treatment options are available, beginning from oral contraceptives (OCs) to menopausal hormonal replacement therapy (HRT). Menopause is associated with symptoms such as heat waves, mood swings, osteoporosis, the risk of developing heart disease, decreased cognitive function, etc., which have an impact on the quality of life [202,203]. Nowadays, HRT includes several different compounds to reduce these disturbing symptoms; however, studies have shown that the use of E2 alone or in combination with other compounds can lead to unfavorable side effects, such as cardiovascular problems and increased risk of stroke and breast cancer [204-206]. Initially, women who received HRT in their early postmenopausal stage have a lower chance 
of developing cognitive deficits and dementia [207-209]. However, several years after HRT, the risk of dementia increases. There is a high possibility of a therapeutic window for the neuroprotective effects of estrogen, which depends on the patient's age and treatment initiation time after menopause.

Besides the shortcomings of HRT, the use of estrogenic compounds is also arguable in TBI. Most animal studies investigating the neuroprotective effects of estrogen employ E2. Since chronic administration is required for long-term neuroprotection and functional recovery after TBI, the pharmacological development of estrogen-like compounds, which maintain the positive neuroprotective effects of E2 but with none or minimal negative side effects, would be necessary. A recent advance in this line of research was the identification of the promising compound group "Activator of Non-Genomic Estrogen Like Signaling" (ANGELS), such as 4-estren-3 $\alpha, 17 \beta$-diol (estren) [210,211]. Estren mimics the neuroprotective effects of E2 in in vivo mouse NMDA-induced toxicity [212] and a $\beta_{1-42}$-induced neurotoxicity model, while not impacting reproductive tissues [213].

Numerous studies have shown that phytoestrogens such as genistein and formononetin have neuroprotective effects in different animal models of brain injuries both in vitro and in vivo [214-216]. The most studied phytoestrogens are genistein and daidzein. Genistein has neuroprotective effects in a rat model of TBI (Marmarou's) through attenuation of the BBB disruption and prevention against cerebral edema formation [214]. Genistein also reduces kainic acid-induced neuronal cell death in the hippocampus [215]. Formononetin has antitumor, anti-inflammatory, and anti-dyslipidemia effects [217,218]. In a Feeney's weight-drop model, formononetin promoted neuronal proliferation by the activation of interleukin-1 (IL-10) expression in cortical neurons to inhibit neuroinflammation [219]. These compounds exert their ameliorative actions by protecting the DNA and normal mitochondrial functions [220]. They also exert their anti-inflammatory effects by inducing the expression of different antioxidant enzymes [221,222], providing a promising platform for the treatment of TBI.

Selective estrogen receptor modulators (SERMs) are synthetic molecules with remarkable neuroprotective potential [223]. The first SERMs, such as tamoxifen (TMX) and toremifene, are used in the treatment of breast cancer. TMX can act as an ER $\alpha$ antagonist and agonist [224]. TMX crosses the BBB [225] and exerts an E2-like neuroprotective effect in the brain without the peripheral side effects observed in estrogen therapy [226]. TMX treatment decreases the neuronal apoptosis and cerebral infarction volumes by reducing interleukin-1B (IL-1B) production and increasing the neuronal phosphorylated extracellular signal-regulated kinases 1 and 2 (p-ERK1/2) and B-cell lymphoma 2 (Bcl2) expressions [227]. Studies using a rat LFP model [228] demonstrated that the neuronal ER $\alpha$ caspase-3 pathway mediates the neuroprotective action of TMX, suggesting a possible role of TMX in therapeutic interventions for human TBI. Bazedoxifen (BZA), a new-generation SERM molecule, was developed for the treatment of osteoporosis in postmenopausal women [229], with favorable effects on the lipid metabolism and skeleton but without uterus or breast stimulation [230]. In vivo experiments demonstrated that BZA suppressed the TBI-induced activation of the mitogen-activated protein kinase/ nuclear factor kappa $B$ (MAPK/NF- KB) signaling pathway [231]. Furthermore, the BZA treatment reduced BBB damage, functional impairments, and the activation of inflammatory cascades in CCI [231], suggesting that BZA could be a possible option for the treatment of TBI.

Tibolone is a synthetic steroid and a member of the selective tissue estrogenic activity regulators (STEARs) employed in HRT [232]. The 3-OH metabolite of tibolon binds to the ER, while the delta-4 isomer binds to the androgen and progesterone receptors [233]. Tibolone metabolites acting on both the ER $\alpha$ and ER $\beta$ reduce oxidative stress and preserve the mitochondrial membrane potential $[234,235]$. In the CNS, astrocytes are believed to mediate the action of tibolone [236]: in an in vivo experiment, tibolone attenuated the reactive response of the microglia and astrocytes in the brain after a TBI in OVX female mice [237]. 


\section{Conclusions}

Animal and clinical studies indicate that the pathomechanism of TBI is complex. Injury severity, time after injury (hours to days or months/years), and the E2 level significantly influence the possible pharmacological therapeutic interventions after TBI.

The onset of therapeutic interventions for patients with TBI in clinical care units depends on the time required for patient admission and early diagnosis using $\mathrm{CT}$ and MRI. However, based on the molecular events of the neuropathological cascade and TBI timeline, early intervention would be more appropriate for the pharmacological treatment of TBI patients. There are also events of secondary injuries occurring in a delayed manner, so the timing of therapy administration should be adapted to the exact target mechanism of the TBI [238].

Although the results of E2 treatment after TBI in animal models are convincing, clinical studies indicate that E2 use is associated with detrimental effects, such as feminization and increased risk of stroke and tumorigenesis, raising concerns about its overall safety. Estrogenic compounds such as SERMS, phytoestrogens, and ANGELS with selective nonclassical estrogen actions are promising options in the therapeutic management of TBI. Neuroprotective estrogenic compounds may offer a better safety profile than the nonselective E2, thereby avoiding E2's unwanted side effects. Research must continue to find the optimal therapeutic window, dose, and administration route, with special attention addressed to sex differences, age, onset, type, and severity of the TBI. Once these parameters are established, estrogenic compounds could become novel drugs with vast therapeutic potential in TBI.

Author Contributions: E.K. and I.M.A. wrote the manuscript and created the Figure. I.M.A. and E.S.-M. revised critically the manuscript for important intellectual content. E.K., E.S.-M. and I.M.A. gave final approval of the version to be published. All authors have read and agree to the published version of the manuscript.

Funding: This work was supported by the Hungarian Brain Research Program (KTIA_NAP_132014-0001 and 20017-1.2.1-NKP -2017-00002) and OTKA (112807), comprehensive development for implementing smart specialization strategies at the University of Pécs (EFOP-3.6.1.-16-2016-00004), and The role of neuro-inflammation in neurodegeneration: from molecules to clinics (EFOP-3.6.2-162017-00008), the Higher Education Institutional Excellence Programme of the Ministry for Innovation and Technology in Hungary, within the framework of the 5 thematic programs at the University of Pécs.

Acknowledgments: We thank Klaudia Barabás for valuable comments on this manuscript.

Conflicts of Interest: The authors declare no potential conflicts of interest with respect to the research, authorship, and/or publication of this article.

$\begin{array}{ll}\text { Abbreviations } & \\ \text { 3NPA } & \text { 3-nitropropionic acid } \\ \text { ANGELS } & \text { activator of non-genomic estrogen like signaling } \\ \text { AMPA } & \alpha \text {-amino-3-hydroxy5-methyl-4-isoxazole-propionic acid } \\ \text { Bcl2 } & \text { B-cell lymphoma 2 } \\ \text { BZA } & \text { bazedoxifen } \\ \text { BBB } & \text { blood brain barrier } \\ \text { CCI } & \text { controlled cortical impact injury } \\ \text { CORT } & \text { cortisol } \\ \text { CPP } & \text { cerebral perfusion pressure } \\ \text { CREB } & \text { cAMP-responsive element-binding protein } \\ \text { CT } & \text { computed tomography } \\ \text { E2 } & \text { 17 } \beta \text {-estradiol } \\ \text { eNOS } & \text { endothelial nitric oxide synthase }\end{array}$




\begin{tabular}{|c|c|}
\hline EPM & elevated plus maze \\
\hline $\mathrm{ER} \alpha$ & estrogen receptor alpha \\
\hline $\mathrm{ER} \beta$ & estrogen receptor beta \\
\hline ERE & estrogen response element \\
\hline ERK1/2 & extracellular signal-regulated kinase $1 / 2$ \\
\hline FPI & fluid percussion injury \\
\hline FSH & follicle stimulating hormone \\
\hline GFAP & glial fibrillary acidic protein \\
\hline GPER1 & G protein-coupled estrogen receptor 1 \\
\hline GSK3 $\beta$ & glycogen synthase kinase 3 beta \\
\hline HPG & hypothalamic-pituitary-gonadal \\
\hline HRT & hormonal replacement therapy \\
\hline ICP & intracranial pressure \\
\hline KNDy & kisspeptin, neurokinin B and dynorphin \\
\hline $\mathrm{LPF}$ & lateral fluid percussion injury \\
\hline LH & luteinizing hormone \\
\hline MAPK & mitogen-activated protein kinase \\
\hline MFP & midline fluid percussion injury \\
\hline MPP & $\begin{array}{l}\text { 1,3-Bis(4-hydroxyphenyl)-4-methyl-5-(4-(2- } \\
\text { piperidinylethoxy)phenol)-1H-pyrazole } \\
\text { hydrochloride }\end{array}$ \\
\hline MRI & magnetic resonance imaging \\
\hline MWM & Morris water maze \\
\hline $\mathrm{NF}-\kappa \mathrm{B}$ & nuclear factor kappa B \\
\hline NMDA & N-methyl-D-aspartic acid \\
\hline OCs & oral contraceptives \\
\hline OVX & ovariectomized \\
\hline $\mathrm{P} 2 \mathrm{X} 7$ & $\mathrm{P} 2 \mathrm{X}$ purinoceptor 7 \\
\hline $\mathrm{p}$-ERK1/2 & $\begin{array}{l}\text { phosphorylated extracellular signal-regulated kinase } 1 \\
\text { and } 2\end{array}$ \\
\hline РI3K & phosphatidylinositol 3-kinase \\
\hline РНTPР & $\begin{array}{l}\text { 4-(2-Phenyl-5, 7-bis (trifluoromethyl) pyrazolo (1,5-a) } \\
\text { pyrimidine-3- yl) phenol }\end{array}$ \\
\hline SERMs & selective estrogen receptor modulators \\
\hline ROS & reactive oxygen species \\
\hline STEARs & selective tissue estrogenic activity regulators \\
\hline TBI & traumatic brain injury \\
\hline TNF- $\alpha$ & tumor necrosis factor alpha \\
\hline TMX & tamoxifen \\
\hline VGCCs & voltage-gated calcium channels \\
\hline
\end{tabular}

\section{References}

1. Menon, D.K.; Schwab, K.; Wright, D.W.; Maas, A.I. Demographics and clinical assessment working group of the international and interagency initiative toward common data elements for research on traumatic brain injury and psychological health. Position statement: Definition of traumatic brain injury. Arch. Phys. Med. Rehabil. 2010, 91, 1637-1640.

2. Maas, A.I.; Stocchetti, N.; Bullock, R. Moderate and severe traumatic brain injury in adults. Lancet Neurol. 2008, 7, 728-741. [CrossRef]

3. Gustavsson, A.; Svensson, M.; Jacobi, F.; Allgulander, C.; Alonso, J.; Beghi, E.; Dodel, R.; Ekman, M.; Faravelli, C.; Fratiglioni, L.; et al. Cost of disorders of the brain in Europe 2010. Eur. Neuropsychopharmacol. 2011, 21, 718-779. [CrossRef] [PubMed]

4. Marik, P.E.; Varon, J.; Trask, T. Management of head trauma. Chest 2002, 122, 699-711. [CrossRef] [PubMed]

5. Riggio, S.; Wong, M. Neurobehavioral sequelae of traumatic brain injury. Mt. Sinai J. Med. 2009, 76, 163-172. [CrossRef] [PubMed]

6. Baethmann, A.; Maier-Hauff, K.; Kempski, O.; Unterberg, A.; Wahl, M.; Schurer, L. Mediators of brain edema and secondary brain damage. Crit. Care Med. 1988, 16, 972-978. [CrossRef] [PubMed]

7. Marklund, N.; Bakshi, A.; Castelbuono, D.J.; Conte, V.; McIntosh, T.K. Evaluation of pharmacological treatment strategies in traumatic brain injury. Curr. Pharm. Des. 2006, 12, 1645-1680. [CrossRef]

8. Loane, D.J.; Faden, A.I. Neuroprotection for traumatic brain injury: Translational challenges and emerging therapeutic strategies. Trends Pharmacol. Sci. 2010, 31, 596-604. [CrossRef]

9. McConeghy, K.W.; Hatton, J.; Hughes, L.; Cook, A.M. A review of neuroprotection pharmacology and therapies in patients with acute traumatic brain injury. CNS Drugs 2012, 26, 613-636. [CrossRef] 
10. Angele, M.K.; Frantz, M.C.; Chaudry, I.H. Gender and sex hormones influence the response to trauma and sepsis: Potential therapeutic approaches. Clinics (Sao Paulo) 2006, 61, 479-488. [CrossRef]

11. Chaudry, I.H.; Bland, K.I. Cellular mechanisms of injury after major trauma. Br. J. Surg. 2009, 96, 1097-1098. [CrossRef]

12. Haider, A.H.; Crompton, J.G.; Oyetunji, T.; Stevens, K.A.; Efron, D.T.; Kieninger, A.N.; Chang, D.C.; Cornwell, E.E.; Haut, E.R. Females have fewer complications and lower mortality following trauma than similarly injured males: A risk adjusted analysis of adults in the national trauma data bank. Surgery 2009, 146, 308-315. [CrossRef] [PubMed]

13. Day, N.L.; Carle, M.S.; Floyd, C.L. Post-injury administration of a combination of memantine and 17beta-estradiol is protective in a rat model of traumatic brain injury. Neurochem. Int. 2017, 111, 57-68. [CrossRef] [PubMed]

14. Bao, Y.J.; Li, L.Z.; Li, X.G.; Wang, Y.J. 17Beta-estradiol differentially protects cortical pericontusional zone from programmed cell death after traumatic cerebral contusion at distinct stages via non-genomic and genomic pathways. Mol. Cell Neurosci. 2011, 48, 185-194. [CrossRef] [PubMed]

15. O'Connor, C.A.; Cernak, I.; Vink, R. Both estrogen and progesterone attenuate edema formation following diffuse traumatic brain injury in rats. Brain Res. 2005, 1062, 171-174. [CrossRef] [PubMed]

16. Petrone, A.B.; Gatson, J.W.; Simpkins, J.W.; Reed, M.N. Non-feminizing estrogens: A novel neuroprotective therapy. Mol. Cell Endocrinol. 2014, 389, 40-47. [CrossRef]

17. Wright, D.W.; Yeatts, S.D.; Silbergleit, R.; Palesch, Y.Y.; Hertzberg, V.S.; Frankel, M.; Goldstein, F.C.; Caveney, A.F.; Howlett-Smith, H.; Bengelink, E.M.; et al. Very early administration of progesterone for acute traumatic brain injury. N. Engl. J. Med. 2014, 371, 2457-2466. [CrossRef]

18. Mofid, B.; Soltani, Z.; Khaksari, M.; Shahrokhi, N.; Nakhaee, N.; Karamouzian, S.; Ahmadinejad, M.; Maiel, M.; Khazaeli, P. What are the progesterone-induced changes of the outcome and the serum markers of injury, oxidant activity and inflammation in diffuse axonal injury patients? Int. Immunopharmacol. 2016, 32, 103-110. [CrossRef]

19. Duncan, K.A. Estrogen formation and inactivation following TBI: What we know and where we could go. Front. Endocrinol. 2020, 11,345. [CrossRef]

20. Martin-Jimenez, C.; Gaitan-Vaca, D.M.; Areiza, N.; Echeverria, V.; Ashraf, G.M.; Gonzalez, J.; Sahebkar, A.; Garcia-Segura, L.M.; Barreto, G.E. Astrocytes mediate protective actions of estrogenic compounds after traumatic brain injury. Neuroendocrinology 2019, 108, 142-160. [CrossRef]

21. Khaksari, M.; Soltani, Z.; Shahrokhi, N. Effects of female sex steroids administration on pathophysiologic mechanisms in traumatic brain injury. Transl. Stroke Res. 2018, 9, 393-416. [CrossRef]

22. Spani, C.B.; Braun, D.J.; Van Eldik, L.J. Sex-related responses after traumatic brain injury: Considerations for preclinical modeling. Front. Neuroendocrinol. 2018, 50, 52-66. [CrossRef] [PubMed]

23. Santiago, L.A.; Oh, B.C.; Dash, P.K.; Holcomb, J.B.; Wade, C.E. A clinical comparison of penetrating and blunt traumatic brain injuries. Brain Inj. 2012, 26, 107-125. [CrossRef] [PubMed]

24. Lee, J.J.; Segar, D.J.; Asaad, W.F. Comprehensive assessment of isolated traumatic subarachnoid hemorrhage. J. Neurotrauma. 2014, 31, 595-609. [CrossRef] [PubMed]

25. McGinn, M.J.; Povlishock, J.T. Pathophysiology of traumatic brain injury. Neurosurg. Clin. N. Am. 2016, 27, 397-407. [CrossRef] [PubMed]

26. McKee, A.C.; Daneshvar, D.H. The neuropathology of traumatic brain injury. Handb. Clin. Neurol. 2015, 127, 45-66.

27. Graham, D.I.; Gennarelli, T.A.; McIntosh, T.K. Trauma. In Greenfield's Neuropathology; Graham, D.I., Lantos, P.L., Eds.; Arnold: London, UK, 2002.

28. Mondello, S.; Jeromin, A.; Buki, A.; Bullock, R.; Czeiter, E.; Kovacs, N.; Barzo, P.; Schmid, K.; Tortella, F.; Wang, K.K.; et al. Glial neuronal ratio: A novel index for differentiating injury type in patients with severe traumatic brain injury. J. Neurotrauma 2012, 29, 1096-1104. [CrossRef]

29. Papa, L.; Lewis, L.M.; Falk, J.L.; Zhang, Z.; Silvestri, S.; Giordano, P.; Brophy, G.M.; Demery, J.A.; Dixit, N.K.; Ferguson, I.; et al. Elevated levels of serum glial fibrillary acidic protein breakdown products in mild and moderate traumatic brain injury are associated with intracranial lesions and neurosurgical intervention. Ann. Emerg. Med. 2012, 59, 471-483. [CrossRef]

30. Wang, K.K.; Yang, Z.; Yue, J.K.; Zhang, Z.; Winkler, E.A.; Puccio, A.M.; Diaz-Arrastia, R.; Lingsma, H.F.; Yuh, E.L.; Mukherjee, P.; et al. Plasma anti-glial fibrillary acidic protein autoantibody levels during the acute and chronic phases of traumatic brain injury: A transforming research and clinical knowledge in traumatic brain injury pilot study. J. Neurotrauma 2016, 33, 1270-1277. [CrossRef]

31. Bramlett, H.M.; Dietrich, W.D. Pathophysiology of cerebral ischemia and brain trauma: Similarities and differences. J. Cereb. Blood Flow. Metab. 2004, 24, 133-150. [CrossRef]

32. Saatman, K.E.; Creed, J.; Raghupathi, R. Calpain as a therapeutic target in traumatic brain injury. Neurotherapeutics 2010, 7, 31-42. [CrossRef]

33. Bullock, R.; Zauner, A.; Woodward, J.J.; Myseros, J.; Choi, S.C.; Ward, J.D.; Marmarou, A.; Young, H.F. Factors affecting excitatory amino acid release following severe human head injury. J. Neurosurg. 1998, 89, 507-518. [CrossRef] [PubMed]

34. Koura, S.S.; Doppenberg, E.M.; Marmarou, A.; Choi, S.; Young, H.F.; Bullock, R. Relationship between excitatory amino acid release and outcome after severe human head injury. Acta. Neurochir. Suppl. 1998, 71, 244-246. [PubMed]

35. Chamoun, R.; Suki, D.; Gopinath, S.P.; Goodman, J.C.; Robertson, C. Role of extracellular glutamate measured by cerebral microdialysis in severe traumatic brain injury. J. Neurosurg. 2010, 113, 564-570. [CrossRef] [PubMed] 
36. Lozano, D.; Gonzales-Portillo, G.S.; Acosta, S.; de la Pena, I.; Tajiri, N.; Kaneko, Y.; Borlongan, C.V. Neuroinflammatory responses to traumatic brain injury: Etiology, clinical consequences, and therapeutic opportunities. Neuropsychiatr. Dis. Treat. 2015, 11, 97-106.

37. Katayama, Y.; Becker, D.P.; Tamura, T.; Hovda, D.A. Massive increases in extracellular potassium and the indiscriminate release of glutamate following concussive brain injury. J. Neurosurg. 1990, 73, 889-900. [CrossRef]

38. Nilsson, P.; Hillered, L.; Olsson, Y.; Sheardown, M.J.; Hansen, A.J. Regional changes in interstitial $\mathrm{K}^{+}$and Ca ${ }^{2+}$ levels following cortical compression contusion trauma in rats. J. Cereb. Blood Flow Metab. 1993, 13, 183-192. [CrossRef]

39. Reinert, M.; Khaldi, A.; Zauner, A.; Doppenberg, E.; Choi, S.; Bullock, R. High level of extracellular potassium and its correlates after severe head injury: Relationship to high intracranial pressure. J. Neurosurg. 2000, 93, 800-807. [CrossRef]

40. Tang, L.; Gamal El-Din, T.M.; Payandeh, J.; Martinez, G.Q.; Heard, T.M.; Scheuer, T.; Zheng, N.; Catterall, W.A. Structural basis for Ca2+ selectivity of a voltage-gated calcium channel. Nature 2014, 505, 56-61. [CrossRef]

41. Stanika, R.I.; Villanueva, I.; Kazanina, G.; Andrews, S.B.; Pivovarova, N.B. Comparative impact of voltage-gated calcium channels and NMDA receptors on mitochondria-mediated neuronal injury. J. Neurosci. 2012, 32, 6642-6650. [CrossRef]

42. Arbeloa, J.; Perez-Samartin, A.; Gottlieb, M.; Matute, C. P2X7 receptor blockade prevents ATP excitotoxicity in neurons and reduces brain damage after ischemia. Neurobiol. Dis. 2012, 45, 954-961. [CrossRef]

43. Blennow, K.; Hardy, J.; Zetterberg, H. The neuropathology and neurobiology of traumatic brain injury. Neuron 2012, 76, 886-899. [CrossRef] [PubMed]

44. Masel, B.E.; DeWitt, D.S. Traumatic brain injury: A disease process, not an event. J. Neurotrauma 2010, 27, 1529-1540. [CrossRef] [PubMed]

45. Reeves, T.M.; Greer, J.E.; Vanderveer, A.S.; Phillips, L.L. Proteolysis of submembrane cytoskeletal proteins ankyrin-G and alphaII-spectrin following diffuse brain injury: A role in white matter vulnerability at Nodes of Ranvier. Brain Pathol. 2010, 20, 1055-1068. [CrossRef] [PubMed]

46. Keane, R.W.; Kraydieh, S.; Lotocki, G.; Alonso, O.F.; Aldana, P.; Dietrich, W.D. Apoptotic and antiapoptotic mechanisms after traumatic brain injury. J. Cereb. Blood Flow Metab. 2001, 21, 1189-1198. [CrossRef]

47. Kurz, J.E.; Hamm, R.J.; Singleton, R.H.; Povlishock, J.T.; Churn, S.B. A persistent change in subcellular distribution of calcineurin following fluid percussion injury in the rat. Brain Res. 2005, 1048, 153-160. [CrossRef]

48. Kurz, J.E.; Parsons, J.T.; Rana, A.; Gibson, C.J.; Hamm, R.J.; Churn, S.B. A significant increase in both basal and maximal calcineurin activity following fluid percussion injury in the rat. J. Neurotrauma 2005, 22, 476-490. [CrossRef]

49. Walker, K.R.; Tesco, G. Molecular mechanisms of cognitive dysfunction following traumatic brain injury. Front. Aging Neurosci. 2013, 5, 29. [CrossRef]

50. Bunker, J.M.; Wilson, L.; Jordan, M.A.; Feinstein, S.C. Modulation of microtubule dynamics by tau in living cells: Implications for development and neurodegeneration. Mol. Biol. Cell 2004, 15, 2720-2728. [CrossRef]

51. Maeda, S.; Sahara, N.; Saito, Y.; Murayama, M.; Yoshiike, Y.; Kim, H.; Miyasaka, T.; Murayama, S.; Ikai, A.; Takashima, A. Granular tau oligomers as intermediates of tau filaments. Biochemistry 2007, 46, 3856-3861. [CrossRef]

52. Di Pietro, V.; Lazzarino, G.; Amorini, A.M.; Tavazzi, B.; D’Urso, S.; Longo, S.; Vagnozzi, R.; Signoretti, S.; Clementi, E.; Giardina, B.; et al. Neuroglobin expression and oxidant/antioxidant balance after graded traumatic brain injury in the rat. Free Radic. Biol. Med. 2014, 69, 258-264. [CrossRef]

53. Sahuquillo, J.; Vilalta, A. Cooling the injured brain: How does moderate hypothermia influence the pathophysiology of traumatic brain injury. Curr. Pharm. Des. 2007, 13, 2310-2322. [CrossRef]

54. Acosta, S.A.; Tajiri, N.; Shinozuka, K.; Ishikawa, H.; Grimmig, B.; Diamond, D.M.; Sanberg, P.R.; Bickford, P.C.; Kaneko, Y.; Borlongan, C.V. Long-term upregulation of inflammation and suppression of cell proliferation in the brain of adult rats exposed to traumatic brain injury using the controlled cortical impact model. PLoS ONE 2013, 8, e53376. [CrossRef]

55. Rubiano, A.M.; Sanchez, A.I.; Estebanez, G.; Peitzman, A.; Sperry, J.; Puyana, J.C. The effect of admission spontaneous hypothermia on patients with severe traumatic brain injury. Injury 2013, 44, 1219-1225. [CrossRef] [PubMed]

56. Feeney, D.M.; Boyeson, M.G.; Linn, R.T.; Murray, H.M.; Dail, W.G. Responses to cortical injury: I. Methodology and local effects of contusions in the rat. Brain Res. 1981, 211,67-77. [CrossRef]

57. Shapira, Y.; Shohami, E.; Sidi, A.; Soffer, D.; Freeman, S.; Cotev, S. Experimental closed head injury in rats: Mechanical, pathophysiologic, and neurologic properties. Crit. Care Med. 1988, 16, 258-265. [CrossRef] [PubMed]

58. Buki, A.; Kovesdi, E.; Pal, J.; Czeiter, E. Clinical and model research of neurotrauma. Methods Mol. Biol. $2009,566,41-55$.

59. Xiong, Y.; Mahmood, A.; Chopp, M. Animal models of traumatic brain injury. Nat. Rev. Neurosci. 2013, 14, 128-142. [CrossRef]

60. Dixon, C.E.; Clifton, G.L.; Lighthall, J.W.; Yaghmai, A.A.; Hayes, R.L. A controlled cortical impact model of traumatic brain injury in the rat. J. Neurosci. Methods 1991, 39, 253-262. [CrossRef]

61. Chen, G.; Shi, J.; Jin, W.; Wang, L.; Xie, W.; Sun, J.; Hang, C. Progesterone administration modulates TLRs/NF-kappaB signaling pathway in rat brain after cortical contusion. Ann. Clin. Lab. Sci. 2008, 38, 65-74.

62. Smith, S.L.; Hall, E.D. Mild pre- and posttraumatic hypothermia attenuates blood-brain barrier damage following controlled cortical impact injury in the rat. J. Neurotrauma 1996, 13, 1-9. [CrossRef]

63. Thompson, H.J.; Lifshitz, J.; Marklund, N.; Grady, M.S.; Graham, D.I.; Hovda, D.A.; McIntosh, T.K. Lateral fluid percussion brain injury: A 15-year review and evaluation. J. Neurotrauma 2005, 22, 42-75. [CrossRef] 
64. Alder, J.; Fujioka, W.; Lifshitz, J.; Crockett, D.P.; Thakker-Varia, S. Lateral fluid percussion: Model of traumatic brain injury in mice. J. Vis. Exp. 2011. [CrossRef] [PubMed]

65. O'Connor, W.T.; Smyth, A.; Gilchrist, M.D. Animal models of traumatic brain injury: A critical evaluation. Pharmacol. Ther. 2011, 130, 106-113. [CrossRef] [PubMed]

66. McIntosh, T.K.; Vink, R.; Noble, L.; Yamakami, I.; Fernyak, S.; Soares, H.; Faden, A.L. Traumatic brain injury in the rat: Characterization of a lateral fluid-percussion model. Neuroscience 1989, 28, 233-244. [CrossRef]

67. Hicks, R.; Soares, H.; Smith, D.; McIntosh, T. Temporal and spatial characterization of neuronal injury following lateral fluidpercussion brain injury in the rat. Acta. Neuropathol. 1996, 91, 236-246. [CrossRef]

68. Marmarou, A.; Foda, M.A.; van den Brink, W.; Campbell, J.; Kita, H.; Demetriadou, K. A new model of diffuse brain injury in rats Part I: Pathophysiology and biomechanics. J. Neurosurg. 1994, 80, 291-300. [CrossRef]

69. Albert-Weissenberger, C.; Varrallyay, C.; Raslan, F.; Kleinschnitz, C.; Siren, A.L. An experimental protocol for mimicking pathomechanisms of traumatic brain injury in mice. Exp. Transl. Stroke Med. 2012, 4, 1. [CrossRef]

70. Dail, W.G.; Feeney, D.M.; Murray, H.M.; Linn, R.T.; Boyeson, M.G. Responses to cortical injury: II. Widespread depression of the activity of an enzyme in cortex remote from a focal injury. Brain Res. 1981, 211, 79-89. [CrossRef]

71. Morales, D.M.; Marklund, N.; Lebold, D.; Thompson, H.J.; Pitkanen, A.; Maxwell, W.L.; Longhi, L.; Laurer, H.; Maegele, M.; Neugebauer, E.; et al. Experimental models of traumatic brain injury: Do we really need to build a better mousetrap? Neuroscience 2005, 136, 971-989. [CrossRef]

72. Mikawa, S.; Kinouchi, H.; Kamii, H.; Gobbel, G.T.; Chen, S.F.; Carlson, E.; Epstein, C.J.; Chan, P.H. Attenuation of acute and chronic damage following traumatic brain injury in copper, zinc-superoxide dismutase transgenic mice. J. Neurosurg. 1996, 85, 885-891. [CrossRef]

73. Bellander, B.M.; von Holst, H.; Fredman, P.; Svensson, M. Activation of the complement cascade and increase of clusterin in the brain following a cortical contusion in the adult rat. J. Neurosurg. 1996, 85, 468-475. [CrossRef] [PubMed]

74. Chen, Y.; Constantini, S.; Trembovler, V.; Weinstock, M.; Shohami, E. An experimental model of closed head injury in mice: Pathophysiology, histopathology, and cognitive deficits. J. Neurotrauma 1996, 13, 557-568. [CrossRef] [PubMed]

75. Haisenleder, D.J.; Dalkin, A.C.; Ortolano, G.A.; Marshall, J.C.; Shupnik, M.A. A pulsatile gonadotropin-releasing hormone stimulus is required to increase transcription of the gonadotropin subunit genes: Evidence for differential regulation of transcription by pulse frequency in vivo. Endocrinology 1991, 128, 509-517. [CrossRef] [PubMed]

76. Moore, A.M.; Coolen, L.M.; Porter, D.T.; Goodman, R.L.; Lehman, M.N. KNDy cells revisited. Endocrinology 2018, 159, 3219-3234. [CrossRef]

77. Kim, J.H.; Cho, H.T.; Kim, Y.J. The role of estrogen in adipose tissue metabolism: Insights into glucose homeostasis regulation. Endocr. J. 2014, 61, 1055-1067. [CrossRef]

78. Stanikova, D.; Luck, T.; Bae, Y.J.; Thiery, J.; Ceglarek, U.; Engel, C.; Enzenbach, C.; Wirkner, K.; Stanik, J.; Kratzsch, J.; et al. Increased estrogen level can be associated with depression in males. Psychoneuroendocrinology 2018, 87, 196-203. [CrossRef]

79. Boon, W.C.; Chow, J.D.; Simpson, E.R. The multiple roles of estrogens and the enzyme aromatase. Prog. Brain Res. 2010, 181, 209-232.

80. Porter, J.C. Proceedings: Hormonal regulation of breast development and activity. J. Invest Dermatol. 1974, 63, 85-92. [CrossRef]

81. Robertson, H.A.; King, G.J. Plasma concentrations of progesterone, oestrone, oestradiol-17beta and of oestrone sulphate in the pig at implantation, during pregnancy and at parturition. J. Reprod. Fertil. 1974, 40, 133-141. [CrossRef]

82. Park, O.K.; Ramirez, V.D. Spontaneous changes in LHRH release during the rat estrous cycle, as measured with repetitive push-pull perfusions of the pituitary gland in the same female rats. Neuroendocrinology 1989, 50, 66-72. [CrossRef]

83. Srivastava, D.P.; Woolfrey, K.M.; Penzes, P. Insights into rapid modulation of neuroplasticity by brain estrogens. Pharmacol. Rev. 2013, 65, 1318-1350. [CrossRef] [PubMed]

84. Garcia-Segura, L.M.; Wozniak, A.; Azcoitia, I.; Rodriguez, J.R.; Hutchison, R.E.; Hutchison, J.B. Aromatase expression by astrocytes after brain injury: Implications for local estrogen formation in brain repair. Neuroscience 1999, 89, 567-578. [CrossRef]

85. Saldanha, C.J.; Duncan, K.A.; Walters, B.J. Neuroprotective actions of brain aromatase. Front. Neuroendocrinol. 2009, 30, 106-118. [CrossRef] [PubMed]

86. Pedersen, A.L.; Brownrout, J.L.; Saldanha, C.J. Neuroinflammation and neurosteroidogenesis: Reciprocal modulation during injury to the adult zebra finch brain. Physiol. Behav. 2018, 187, 51-56. [CrossRef] [PubMed]

87. Duncan, K.A.; Walters, B.J.; Saldanha, C.J. Traumatized and inflamed-but resilient: Glial aromatization and the avian brain. Horm. Behav. 2013, 63, 208-215. [CrossRef]

88. Fokidis, H.B.; Adomat, H.H.; Kharmate, G.; Hosseini-Beheshti, E.; Guns, E.S.; Soma, K.K. Regulation of local steroidogenesis in the brain and in prostate cancer: Lessons learned from interdisciplinary collaboration. Front. Neuroendocrinol. 2015, 36, 108-129. [CrossRef] [PubMed]

89. Azcoitia, I.; Yague, J.G.; Garcia-Segura, L.M. Estradiol synthesis within the human brain. Neuroscience 2011, 191, 139-147. [CrossRef]

90. Do Rego, J.L.; Seong, J.Y.; Burel, D.; Leprince, J.; Luu-The, V.; Tsutsui, K.; Tonon, M.C.; Pelletier, G.; Vaudry, H. Neurosteroid biosynthesis: Enzymatic pathways and neuroendocrine regulation by neurotransmitters and neuropeptides. Front. Neuroendocrinol. 2009, 30, 259-301. [CrossRef] 
91. Merchenthaler, I.; Dellovade, T.L.; Shughrue, P.J. Neuroprotection by estrogen in animal models of global and focal ischemia. Ann. N. Y. Acad. Sci. 2003, 1007, 89-100. [CrossRef]

92. Pike, A.C.; Brzozowski, A.M.; Hubbard, R.E. A structural biologist's view of the oestrogen receptor. J. Steroid Biochem. Mol. Biol. 2000, 74, 261-268. [CrossRef]

93. Verderame, M.; Scudiero, R. A comparative review on estrogen receptors in the reproductive male tract of non mammalian vertebrates. Steroids 2018, 134, 1-8. [CrossRef] [PubMed]

94. Kuiper, G.G.; Carlsson, B.; Grandien, K.; Enmark, E.; Haggblad, J.; Nilsson, S.; Gustafsson, J.A. Comparison of the ligand binding specificity and transcript tissue distribution of estrogen receptors alpha and beta. Endocrinology 1997, 138, 863-870. [CrossRef] [PubMed]

95. Cersosimo, M.G.; Benarroch, E.E. Estrogen actions in the nervous system: Complexity and clinical implications. Neurology 2015, 85, 263-273. [CrossRef] [PubMed]

96. Marin, R.; Casanas, V.; Perez, J.A.; Fabelo, N.; Fernandez, C.E.; Diaz, M. Oestrogens as modulators of neuronal signalosomes and brain lipid homeostasis related to protection against neurodegeneration. J. Neuroendocrinol. 2013, 25, 1104-1115. [CrossRef] [PubMed]

97. Li, R.; Cui, J.; Shen, Y. Brain sex matters: Estrogen in cognition and Alzheimer's disease. Mol. Cell. Endocrinol. 2014, 389, 13-21. [CrossRef]

98. Shughrue, P.J.; Lane, M.V.; Merchenthaler, I. Comparative distribution of estrogen receptor-alpha and -beta mRNA in the rat central nervous system. J. Comp. Neurol. 1997, 388, 507-525. [CrossRef]

99. Smith, D.F.; Toft, D.O. Steroid receptors and their associated proteins. Mol Endocrinol 1993, 7, 4-11. [PubMed]

100. McKenna, N.J.; Lanz, R.B.; O’Malley, B.W. Nuclear receptor coregulators: Cellular and molecular biology. Endocr. Rev. 1999, 20,321-344. [PubMed]

101. Klinge, C.M. Estrogen receptor interaction with estrogen response elements. Nucleic Acids. Res. 2001, 29, 2905-2919. [CrossRef]

102. Marino, M.; Galluzzo, P.; Ascenzi, P. Estrogen signaling multiple pathways to impact gene transcription. Curr. Genom. 2006, 7, 497-508. [CrossRef]

103. Revankar, C.M.; Cimino, D.F.; Sklar, L.A.; Arterburn, J.B.; Prossnitz, E.R. A transmembrane intracellular estrogen receptor mediates rapid cell signaling. Science 2005, 307, 1625-1630. [CrossRef] [PubMed]

104. Sawe, N.; Steinberg, G.; Zhao, H. Dual roles of the MAPK/ERK1/2 cell signaling pathway after stroke. J. Neurosci. Res. 2008, 86, 1659-1669. [CrossRef] [PubMed]

105. Simoncini, T.; Hafezi-Moghadam, A.; Brazil, D.P.; Ley, K.; Chin, W.W.; Liao, J.K. Interaction of oestrogen receptor with the regulatory subunit of phosphatidylinositol-3-OH kinase. Nature 2000, 407, 538-541. [CrossRef] [PubMed]

106. Malyala, A.; Zhang, C.; Bryant, D.N.; Kelly, M.J.; Ronnekleiv, O.K. PI3K signaling effects in hypothalamic neurons mediated by estrogen. J. Comp. Neurol. 2008, 506, 895-911. [CrossRef]

107. Drevensek, G. 17 $\beta$-Estradiol as a Neuroprotective Agen. In Sex Hormones in Neurodegenerative Processes and Diseases; Drevenšek, G., Ed.; IntechOpen: Rijeka, Croatia, 2018.

108. Abraham, I.M.; Han, S.K.; Todman, M.G.; Korach, K.S.; Herbison, A.E. Estrogen receptor beta mediates rapid estrogen actions on gonadotropin-releasing hormone neurons in vivo. J. Neurosci. 2003, 23, 5771-5777. [CrossRef]

109. Carlstrom, L.; Ke, Z.J.; Unnerstall, J.R.; Cohen, R.S.; Pandey, S.C. Estrogen modulation of the cyclic AMP response element-binding protein pathway. Effects of long-term and acute treatments. Neuroendocrinology 2001, 74, 227-243. [CrossRef]

110. Azcoitia, I.; Barreto, G.E.; Garcia-Segura, L.M. Molecular mechanisms and cellular events involved in the neuroprotective actions of estradiol. Analysis of sex differences. Front. Neuroendocrinol. 2019, 55, 100787. [CrossRef]

111. Green, P.S.; Bishop, J.; Simpkins, J.W. 17 alpha-estradiol exerts neuroprotective effects on SK-N-SH cells. J. Neurosci. 1997, 17, 511-515. [CrossRef]

112. Green, P.S.; Gordon, K.; Simpkins, J.W. Phenolic a ring requirement for the neuroprotective effects of steroids. J. Steroid Biochem. Mol. Biol. 1997, 63, 229-235. [CrossRef]

113. Green, P.S.; Gridley, K.E.; Simpkins, J.W. Nuclear estrogen receptor-independent neuroprotection by estratrienes: A novel interaction with glutathione. Neuroscience 1998, 84, 7-10. [CrossRef]

114. Pike, C.J. Estrogen modulates neuronal Bcl-xL expression and beta-amyloid-induced apoptosis: Relevance to Alzheimer's disease. J. Neurochem. 1999, 72, 1552-1563. [CrossRef] [PubMed]

115. Behl, C.; Widmann, M.; Trapp, T.; Holsboer, F. 17-beta estradiol protects neurons from oxidative stress-induced cell death in vitro. Biochem. Biophys. Res. Commun. 1995, 216, 473-482. [CrossRef] [PubMed]

116. Sawada, H.; Ibi, M.; Kihara, T.; Urushitani, M.; Honda, K.; Nakanishi, M.; Akaike, A.; Shimohama, S. Mechanisms of antiapoptotic effects of estrogens in nigral dopaminergic neurons. FASEB J. 2000, 14, 1202-1214. [CrossRef] [PubMed]

117. Perez, E.; Liu, R.; Yang, S.H.; Cai, Z.Y.; Covey, D.F.; Simpkins, J.W. Neuroprotective effects of an estratriene analog are estrogen receptor independent in vitro and in vivo. Brain Res. 2005, 1038, 216-222. [CrossRef]

118. Wise, P.M.; Dubal, D.B. Estradiol protects against ischemic brain injury in middle-aged rats. Biol. Reprod. 2000, 63, 982-985. [CrossRef]

119. Engler-Chiurazzi, E.B.; Singh, M.; Simpkins, J.W. From the $90^{\prime}$ s to now: A brief historical perspective on more than two decades of estrogen neuroprotection. Brain Res. 2016, 1633, 96-100. [CrossRef] 
120. Fukuda, K.; Yao, H.; Ibayashi, S.; Nakahara, T.; Uchimura, H.; Fujishima, M.; Hall, E.D. Ovariectomy exacerbates and estrogen replacement attenuates photothrombotic focal ischemic brain injury in rats. Stroke 2000, 31, 155-160. [CrossRef]

121. Morissette, M.; Le Saux, M.; D'Astous, M.; Jourdain, S.; Al Sweidi, S.; Morin, N.; Estrada-Camarena, E.; Mendez, P.; Garcia-Segura, L.M.; Di Paolo, T. Contribution of estrogen receptors alpha and beta to the effects of estradiol in the brain. J. Steroid Biochem. Mol. Biol. 2008, 108, 327-338. [CrossRef]

122. Al Sweidi, S.; Sanchez, M.G.; Bourque, M.; Morissette, M.; Dluzen, D.; Di Paolo, T. Oestrogen receptors and signalling pathways: Implications for neuroprotective effects of sex steroids in Parkinson's disease. J. Neuroendocrinol. 2012, 24, 48-61. [CrossRef]

123. Guerra, B.; Diaz, M.; Alonso, R.; Marin, R. Plasma membrane oestrogen receptor mediates neuroprotection against beta-amyloid toxicity through activation of Raf-1/MEK/ERK cascade in septal-derived cholinergic SN56 cells. J. Neurochem. 2004, 91, 99-109. [CrossRef]

124. Marin, R.; Guerra, B.; Morales, A.; Diaz, M.; Alonso, R. An oestrogen membrane receptor participates in estradiol actions for the prevention of amyloid-beta peptide1-40-induced toxicity in septal-derived cholinergic SN56 cells. J. Neurochem. 2003, 85, 1180-1189. [CrossRef] [PubMed]

125. Spence, R.D.; Wisdom, A.J.; Cao, Y.; Hill, H.M.; Mongerson, C.R.; Stapornkul, B.; Itoh, N.; Sofroniew, M.V.; Voskuhl, R.R. Estrogen mediates neuroprotection and anti-inflammatory effects during EAE through ERalpha signaling on astrocytes but not through ERbeta signaling on astrocytes or neurons. J. Neurosci. 2013, 33, 10924-10933. [CrossRef] [PubMed]

126. Bramlett, H.M.; Dietrich, W.D. Neuropathological protection after traumatic brain injury in intact female rats versus males or ovariectomized females. J. Neurotrauma 2001, 18, 891-900. [CrossRef] [PubMed]

127. Roof, R.L.; Hall, E.D. Estrogen-related gender difference in survival rate and cortical blood flow after impact-acceleration head injury in rats. J. Neurotrauma 2000, 17, 1155-1169. [CrossRef] [PubMed]

128. Lu, H.; Ma, K.; Jin, L.; Zhu, H.; Cao, R. 17beta-estradiol rescues damages following traumatic brain injury from molecule to behavior in mice. J. Cell. Physiol. 2018, 233, 1712-1722. [CrossRef]

129. Khaksari, M.; Hajializadeh, Z.; Shahrokhi, N.; Esmaeili-Mahani, S. Changes in the gene expression of estrogen receptors involved in the protective effect of estrogen in rat's trumatic brain injury. Brain Res. 2015, 1618, 1-8. [CrossRef]

130. Shahrokhi, N.; Khaksari, M.; Soltani, Z.; Mahmoodi, M.; Nakhaee, N. Effect of sex steroid hormones on brain edema, intracranial pressure, and neurologic outcomes after traumatic brain injury. Can. J. Physiol. Pharmacol. 2010, 88, 414-421. [CrossRef]

131. Duckles, S.P.; Krause, D.N. Mechanisms of cerebrovascular protection: Oestrogen, inflammation and mitochondria. Acta. Physiol. (Oxf) 2011, 203, 149-154. [CrossRef]

132. Chakrabarti, S.; Lekontseva, O.; Davidge, S.T. Estrogen is a modulator of vascular inflammation. IUBMB Life 2008, 60, 376-382. [CrossRef]

133. Naderi, V.; Khaksari, M.; Abbasi, R.; Maghool, F. Estrogen provides neuroprotection against brain edema and blood brain barrier disruption through both estrogen receptors alpha and beta following traumatic brain injury. Iran. J. Basic Med. Sci. 2015, $18,138-144$.

134. Nakagami, F.; Nakagami, H.; Osako, M.K.; Iwabayashi, M.; Taniyama, Y.; Doi, T.; Shimizu, H.; Shimamura, M.; Rakugi, H.; Morishita, R. Estrogen attenuates vascular remodeling in Lp(a) transgenic mice. Atherosclerosis 2010, 211, 41-47. [CrossRef] [PubMed]

135. Bake, S.; Friedman, J.A.; Sohrabji, F. Reproductive age-related changes in the blood brain barrier: Expression of IgG and tight junction proteins. Microvasc. Res. 2009, 78, 413-424. [CrossRef] [PubMed]

136. Burek, M.; Arias-Loza, P.A.; Roewer, N.; Forster, C.Y. Claudin-5 as a novel estrogen target in vascular endothelium. Arterioscler. Thromb. Vasc. Biol. 2010, 30, 298-304. [CrossRef] [PubMed]

137. Guo, J.; Krause, D.N.; Horne, J.; Weiss, J.H.; Li, X.; Duckles, S.P. Estrogen-receptor-mediated protection of cerebral endothelial cell viability and mitochondrial function after ischemic insult in vitro. J. Cereb. Blood Flow Metab. 2010, 30, 545-554. [CrossRef]

138. Simpkins, J.W.; Dykens, J.A. Mitochondrial mechanisms of estrogen neuroprotection. Brain Res. Rev. 2008, 57, 421-430. [CrossRef]

139. Sarkar, S.; Jun, S.; Simpkins, J.W. Estrogen amelioration of Abeta-induced defects in mitochondria is mediated by mitochondrial signaling pathway involving ERbeta, AKAP and Drp1. Brain Res. 2015, 1616, 101-111. [CrossRef]

140. Nilsen, J.; Brinton, R.D. Mitochondria as therapeutic targets of estrogen action in the central nervous system. Curr. Drug Targets CNS Neurol. Disord. 2004, 3, 297-313. [CrossRef]

141. Zhao, L.; Brinton, R.D. Estrogen receptor alpha and beta differentially regulate intracellular $\mathrm{Ca}\left({ }^{2+}\right)$ dynamics leading to ERK phosphorylation and estrogen neuroprotection in hippocampal neurons. Brain Res. 2007, 1172, 48-59. [CrossRef]

142. Zup, S.L.; Madden, A.M. Gonadal hormone modulation of intracellular calcium as a mechanism of neuroprotection. Front. Neuroendocrinol. 2016, 42, 40-52. [CrossRef]

143. Sribnick, E.A.; Del Re, A.M.; Ray, S.K.; Woodward, J.J.; Banik, N.L. Estrogen attenuates glutamate-induced cell death by inhibiting $\mathrm{Ca} 2+$ influx through L-type voltage-gated $\mathrm{Ca}^{2+}$ channels. Brain Res. 2009, 1276, 159-170. [CrossRef]

144. Alkayed, N.J.; Goto, S.; Sugo, N.; Joh, H.D.; Klaus, J.; Crain, B.J.; Bernard, O.; Traystman, R.J.; Hurn, P.D. Estrogen and Bcl-2: Gene induction and effect of transgene in experimental stroke. J. Neurosci. 2001, 21, 7543-7550. [CrossRef] [PubMed]

145. Zhang, Y.; Bhavnani, B.R. Glutamate-induced apoptosis in neuronal cells is mediated via caspase-dependent and independent mechanisms involving calpain and caspase-3 proteases as well as apoptosis inducing factor (AIF) and this process is inhibited by equine estrogens. BMC Neurosci. 2006, 7, 49. [CrossRef] [PubMed]

146. Raghupathi, R. Cell death mechanisms following traumatic brain injury. Brain Pathol. 2004, 14, 215-222. [CrossRef] [PubMed] 
147. Guo, J.M.; Shu, H.; Wang, L.; Xu, J.J.; Niu, X.C.; Zhang, L. SIRT1-dependent AMPK pathway in the protection of estrogen against ischemic brain injury. CNS Neurosci. Ther. 2017, 23, 360-369. [CrossRef] [PubMed]

148. Nuzzo, M.T.; Fiocchetti, M.; Totta, P.; Melone, M.A.B.; Cardinale, A.; Fusco, F.R.; Gustincich, S.; Persichetti, F.; Ascenzi, P.; Marino, M. Huntingtin polyQ mutation Impairs the 17beta-estradiol/neuroglobin pathway devoted to neuron survival. Mol. Neurobiol. 2017, 54, 6634-6646. [CrossRef] [PubMed]

149. De Marinis, E.; Acaz-Fonseca, E.; Arevalo, M.A.; Ascenzi, P.; Fiocchetti, M.; Marino, M.; Garcia-Segura, L.M. 17beta-Oestradiol antiinflammatory effects in primary astrocytes require oestrogen receptor beta-mediated neuroglobin up-regulation. J. Neuroendocrinol. 2013, 25, 260-270. [CrossRef]

150. Yao, M.; Nguyen, T.V.; Pike, C.J. Estrogen regulates Bcl-w and Bim expression: Role in protection against beta-amyloid peptideinduced neuronal death. J. Neurosci. 2007, 27, 1422-1433. [CrossRef]

151. Smith, J.A.; Zhang, R.; Varma, A.K.; Das, A.; Ray, S.K.; Banik, N.L. Estrogen partially down-regulates PTEN to prevent apoptosis in VSC4.1 motoneurons following exposure to IFN-gamma. Brain Res. 2009, 1301, 163-170. [CrossRef]

152. Li, L.Z.; Bao, Y.J.; Zhao, M. 17beta-estradiol attenuates programmed cell death in cortical pericontusional zone following traumatic brain injury via upregulation of ERalpha and inhibition of caspase-3 activation. Neurochem. Int. 2011, 58, 126-133. [CrossRef]

153. Aliev, G.; Smith, M.A.; Seyidov, D.; Neal, M.L.; Lamb, B.T.; Nunomura, A.; Gasimov, E.K.; Vinters, H.V.; Perry, G.; LaManna, J.C.; et al. The role of oxidative stress in the pathophysiology of cerebrovascular lesions in Alzheimer's disease. Brain Pathol. 2002, 12, 21-35. [CrossRef]

154. Calabrese, V.; Scapagnini, G.; Giuffrida Stella, A.M.; Bates, T.E.; Clark, J.B. Mitochondrial involvement in brain function and dysfunction: Relevance to aging, neurodegenerative disorders and longevity. Neurochem. Res. 2001, 26, 739-764. [CrossRef] [PubMed]

155. Wang, X.; Dykens, J.A.; Perez, E.; Liu, R.; Yang, S.; Covey, D.F.; Simpkins, J.W. Neuroprotective effects of 17beta-estradiol and nonfeminizing estrogens against $\mathrm{H}_{2} \mathrm{O}_{2}$ toxicity in human neuroblastoma SK-N-SH cells. Mol. Pharmacol. 2006, 70, 395-404. [CrossRef] [PubMed]

156. Ishihara, Y.; Takemoto, T.; Ishida, A.; Yamazaki, T. Protective actions of 17beta-estradiol and progesterone on oxidative neuronal injury induced by organometallic compounds. Oxid. Med. Cell. Longev. 2015, 2015, 343706. [CrossRef] [PubMed]

157. Filardo, E.J.; Quinn, J.A.; Bland, K.I.; Frackelton, A.R., Jr. Estrogen-induced activation of Erk-1 and Erk-2 requires the G proteincoupled receptor homolog, GPR30, and occurs via trans-activation of the epidermal growth factor receptor through release of HB-EGF. Mol. Endocrinol. 2000, 14, 1649-1660. [CrossRef] [PubMed]

158. Murakoshi, M.; Ikada, R.; Tagawa, M. Regulation of prostatic glutathione-peroxidase (GSH-PO) in rats treated with a combination of testosterone and 17 beta-estradiol. J. Toxicol. Sci. 1999, 24, 415-420. [CrossRef] [PubMed]

159. Vegeto, E.; Benedusi, V.; Maggi, A. Estrogen anti-inflammatory activity in brain: A therapeutic opportunity for menopause and neurodegenerative diseases. Front. Neuroendocrinol. 2008, 29, 507-519. [CrossRef] [PubMed]

160. Wang, X.; Simpkins, J.W.; Dykens, J.A.; Cammarata, P.R. Oxidative damage to human lens epithelial cells in culture: Estrogen protection of mitochondrial potential, ATP, and cell viability. Investig. Ophthalmol. Vis. Sci. 2003, 44, 2067-2075. [CrossRef]

161. Vegeto, E.; Belcredito, S.; Ghisletti, S.; Meda, C.; Etteri, S.; Maggi, A. The endogenous estrogen status regulates microglia reactivity in animal models of neuroinflammation. Endocrinology 2006, 147, 2263-2272. [CrossRef]

162. Zendedel, A.; Monnink, F.; Hassanzadeh, G.; Zaminy, A.; Ansar, M.M.; Habib, P.; Slowik, A.; Kipp, M.; Beyer, C. Estrogen attenuates local inflammasome expression and activation after spinal cord injury. Mol. Neurobiol. 2018, 55, 1364-1375. [CrossRef]

163. Perez-Alvarez, M.J.; Villa Gonzalez, M.; Benito-Cuesta, I.; Wandosell, F.G. Role of mTORC1 controlling proteostasis after brain ischemia. Front. Neurosci. 2018, 12, 60. [CrossRef]

164. Zhang, Z.; Qin, P.; Deng, Y.; Ma, Z.; Guo, H.; Guo, H.; Hou, Y.; Wang, S.; Zou, W.; Sun, Y.; et al. The novel estrogenic receptor GPR30 alleviates ischemic injury by inhibiting TLR4-mediated microglial inflammation. J. Neuroinflamm. 2018, 15, 206. [CrossRef] [PubMed]

165. Lopez Rodriguez, A.B.; Mateos Vicente, B.; Romero-Zerbo, S.Y.; Rodriguez-Rodriguez, N.; Bellini, M.J.; Rodriguez de Fonseca, F.; Bermudez-Silva, F.J.; Azcoitia, I.; Garcia-Segura, L.M.; Viveros, M.P. Estradiol decreases cortical reactive astrogliosis after brain injury by a mechanism involving cannabinoid receptors. Cereb. Cortex 2011, 21, 2046-2055. [CrossRef] [PubMed]

166. Sarkaki, A.R.; Khaksari Haddad, M.; Soltani, Z.; Shahrokhi, N.; Mahmoodi, M. Time- and dose-dependent neuroprotective effects of sex steroid hormones on inflammatory cytokines after a traumatic brain injury. J Neurotrauma 2013, 30, 47-54. [CrossRef] [PubMed]

167. Conti, A.; Guli, C.; La Torre, D.; Tomasello, C.; Angileri, F.F.; Aguennouz, M. Role of inflammation and oxidative stress mediators in gliomas. Cancers (Basel) 2010, 2, 693-712. [CrossRef]

168. Ospina, J.A.; Brevig, H.N.; Krause, D.N.; Duckles, S.P. Estrogen suppresses IL-1beta-mediated induction of COX-2 pathway in rat cerebral blood vessels. Am. J. Physiol. Heart Circ. Physiol. 2004, 286, H2010-9. [CrossRef]

169. Ghisletti, S.; Meda, C.; Maggi, A.; Vegeto, E. 17beta-estradiol inhibits inflammatory gene expression by controlling NF-kappaB intracellular localization. Mol. Cell. Biol. 2005, 25, 2957-2968. [CrossRef]

170. Rahman, A.; Fazal, F. Blocking NF-kappaB: An inflammatory issue. Proc. Am. Thorac. Soc. 2011, 8, 497-503. [CrossRef]

171. Sohrabji, F.; Miranda, R.C.; Toran-Allerand, C.D. Identification of a putative estrogen response element in the gene encoding brain-derived neurotrophic factor. Proc. Natl. Acad. Sci. U.S.A. 1995, 92, 11110-11114. [CrossRef] 
172. Leon, R.L.; Li, X.; Huber, J.D.; Rosen, C.L. Worsened outcome from middle cerebral artery occlusion in aged rats receiving 17beta-estradiol. Endocrinology 2012, 153, 3386-3393. [CrossRef]

173. Suzuki, S.; Brown, C.M.; Dela Cruz, C.D.; Yang, E.; Bridwell, D.A.; Wise, P.M. Timing of estrogen therapy after ovariectomy dictates the efficacy of its neuroprotective and antiinflammatory actions. Proc. Natl. Acad. Sci. U.S.A. 2007, 104, 6013-6018. [CrossRef]

174. Selvamani, A.; Sohrabji, F. Reproductive age modulates the impact of focal ischemia on the forebrain as well as the effects of estrogen treatment in female rats. Neurobiol. Aging 2010, 31, 1618-1628. [CrossRef] [PubMed]

175. Sohrabji, F.; Bake, S.; Lewis, D.K. Age-related changes in brain support cells: Implications for stroke severity. Neurochem. Int. 2013, 63, 291-301. [CrossRef] [PubMed]

176. Westwood, F.R. The female rat reproductive cycle: A practical histological guide to staging. Toxicol. Pathol. 2008, 36, 375-384. [CrossRef] [PubMed]

177. Barton, D.J.; Kumar, R.G.; McCullough, E.H.; Galang, G.; Arenth, P.M.; Berga, S.L.; Wagner, A.K. Persistent hypogonadotropic hypogonadism in men after severe traumatic brain injury: Temporal hormone profiles and outcome prediction. J. Head Trauma Rehabil. 2016, 31, 277-287. [CrossRef] [PubMed]

178. Carlson, N.E.; Brenner, L.A.; Wierman, M.E.; Harrison-Felix, C.; Morey, C.; Gallagher, S.; Ripley, D. Hypogonadism on admission to acute rehabilitation is correlated with lower functional status at admission and discharge. Brain Inj. 2009, 23, 336-344. [CrossRef]

179. Wagner, A.K.; McCullough, E.H.; Niyonkuru, C.; Ozawa, H.; Loucks, T.L.; Dobos, J.A.; Brett, C.A.; Santarsieri, M.; Dixon, C.E.; Berga, S.L.; et al. Acute serum hormone levels: Characterization and prognosis after severe traumatic brain injury. J. Neurotrauma 2011, 28, 871-888. [CrossRef]

180. Bavisetty, S.; Bavisetty, S.; McArthur, D.L.; Dusick, J.R.; Wang, C.; Cohan, P.; Boscardin, W.J.; Swerdloff, R.; Levin, H.; Chang, D.J.; et al. Chronic hypopituitarism after traumatic brain injury: Risk assessment and relationship to outcome. Neurosurgery 2008, 62, 1080-1094. [CrossRef]

181. Brinton, R.D. Neurosteroids as regenerative agents in the brain: Therapeutic implications. Nat. Rev. Endocrinol. 2013, 9, 241-250. [CrossRef]

182. Ranganathan, P.; Kumar, R.G.; Davis, K.; McCullough, E.H.; Berga, S.L.; Wagner, A.K. Longitudinal sex and stress hormone profiles among reproductive age and post-menopausal women after severe TBI: A case series analysis. Brain Inj. 2016, 30, 452-461. [CrossRef]

183. Melcangi, R.C.; Giatti, S.; Garcia-Segura, L.M. Levels and actions of neuroactive steroids in the nervous system under physiological and pathological conditions: Sex-specific features. Neurosci. Biobehav. Rev. 2016, 67, 25-40. [CrossRef]

184. Chisu, V.; Manca, P.; Lepore, G.; Gadau, S.; Zedda, M.; Farina, V. Testosterone induces neuroprotection from oxidative stress. Effects on catalase activity and 3-nitro-L-tyrosine incorporation into alpha-tubulin in a mouse neuroblastoma cell line. Arch. Ital. Biol. 2006, 144, 63-73. [PubMed]

185. Hammond, J.; Le, Q.; Goodyer, C.; Gelfand, M.; Trifiro, M.; LeBlanc, A. Testosterone-mediated neuroprotection through the androgen receptor in human primary neurons. J. Neurochem. 2001, 77, 1319-1326. [CrossRef] [PubMed]

186. Huppenbauer, C.B.; Tanzer, L.; DonCarlos, L.L.; Jones, K.J. Gonadal steroid attenuation of developing hamster facial motoneuron loss by axotomy: Equal efficacy of testosterone, dihydrotestosterone, and 17-beta estradiol. J. Neurosci. 2005, 25, 4004-4013. [CrossRef] [PubMed]

187. Nguyen, T.V.; Yao, M.; Pike, C.J. Androgens activate mitogen-activated protein kinase signaling: Role in neuroprotection. J. Neurochem. 2005, 94, 1639-1651. [CrossRef]

188. Soustiel, J.F.; Palzur, E.; Nevo, O.; Thaler, I.; Vlodavsky, E. Neuroprotective anti-apoptosis effect of estrogens in traumatic brain injury. J. Neurotrauma 2005, 22, 345-352. [CrossRef]

189. Zolin, S.J.; Vodovotz, Y.; Forsythe, R.M.; Rosengart, M.R.; Namas, R.; Brown, J.B.; Peitzman, A.P.; Billiar, T.R.; Sperry, J.L. The early evolving sex hormone environment is associated with significant outcome and inflammatory response differences after injury. J. Trauma Acute Care Surg. 2015, 78, 451-458. [CrossRef]

190. Beale, E.; Zhu, J.; Belzberg, H. Changes in serum cortisol with age in critically ill patients. Gerontology 2002, 48, 84-92. [CrossRef]

191. May, A.K.; Dossett, L.A.; Norris, P.R.; Hansen, E.N.; Dorsett, R.C.; Popovsky, K.A.; Sawyer, R.G. Estradiol is associated with mortality in critically ill trauma and surgical patients. Crit. Care Med. 2008, 36, 62-68. [CrossRef]

192. Simpson, E.R.; Merrill, J.C.; Hollub, A.J.; Graham-Lorence, S.; Mendelson, C.R. Regulation of estrogen biosynthesis by human adipose cells. Endocr. Rev. 1989, 10, 136-148. [CrossRef]

193. Colantonio, A.; Mar, W.; Escobar, M.; Yoshida, K.; Velikonja, D.; Rizoli, S.; Cusimano, M.; Cullen, N. Women's health outcomes after traumatic brain injury. J. Womens Health (Larchmt) 2010, 19, 1109-1116. [CrossRef]

194. Fortress, A.M.; Avcu, P.; Wagner, A.K.; Dixon, C.E.; Pang, K.C.H. Experimental traumatic brain injury results in estrous cycle disruption, neurobehavioral deficits, and impaired GSK3beta/beta-catenin signaling in female rats. Exp. Neurol. 2019, $315,42-51$. [CrossRef] [PubMed]

195. Barnes, D.E.; Kaup, A.; Kirby, K.A.; Byers, A.L.; Diaz-Arrastia, R.; Yaffe, K. Traumatic brain injury and risk of dementia in older veterans. Neurology 2014, 83, 312-319. [CrossRef] [PubMed]

196. Gardner, R.C.; Burke, J.F.; Nettiksimmons, J.; Kaup, A.; Barnes, D.E.; Yaffe, K. Dementia risk after traumatic brain injury vs nonbrain trauma: The role of age and severity. JAMA Neurol. 2014, 71, 1490-1497. [CrossRef] [PubMed] 
197. Berga, S.L.; Daniels, T.L.; Giles, D.E. Women with functional hypothalamic amenorrhea but not other forms of anovulation display amplified cortisol concentrations. Fertil. Steril. 1997, 67, 1024-1030. [CrossRef]

198. Biller, B.M.; Federoff, H.J.; Koenig, J.I.; Klibanski, A. Abnormal cortisol secretion and responses to corticotropin-releasing hormone in women with hypothalamic amenorrhea. J. Clin. Endocrinol. Metab. 1990, 70, 311-317. [CrossRef] [PubMed]

199. Spratt, D.I.; Kramer, R.S.; Morton, J.R.; Lucas, F.L.; Becker, K.; Longcope, C. Characterization of a prospective human model for study of the reproductive hormone responses to major illness. Am. J. Physiol. Endocrinol. Metab. 2008, 295, E63-E69. [CrossRef]

200. Bughi, S.; Shaw, S.J.; Mahmood, G.; Atkins, R.H.; Szlachcic, Y. Amenorrhea, pregnancy, and pregnancy outcomes in women following spinal cord injury: A retrospective cross-sectional study. Endocr. Pract. Off. J. Am. Coll. Endocrinol. Am. Assoc. Clin. Endocrinol. 2008, 14, 437-441. [CrossRef]

201. Niemeier, J.P.; Perrin, P.B.; Hurst, B.S.; Foureau, D.M.; Huynh, T.T.; Evans, S.L.; Silverman, J.E.; Elise McClannahan, M.; Brusch, B.D.; Newman, M.; et al. A repeated measures pilot comparison of trajectories of fluctuating endogenous hormones in young women with traumatic brain Injury, healthy controls. Behav. Neurol. 2019, 2019, 7694503. [CrossRef]

202. Freedman, M.A. Quality of life and menopause: The role of estrogen. J. Womens Health (Larchmt) 2002, 11, 703-718. [CrossRef]

203. Sherwin, B.B.; Henry, J.F. Brain aging modulates the neuroprotective effects of estrogen on selective aspects of cognition in women: A critical review. Front. Neuroendocr. 2008, 29, 88-113. [CrossRef]

204. Manson, J.E.; Hsia, J.; Johnson, K.C.; Rossouw, J.E.; Assaf, A.R.; Lasser, N.L.; Trevisan, M.; Black, H.R.; Heckbert, S.R.; Detrano, R.; et al. Women's Health Initiative, I., Estrogen plus progestin and the risk of coronary heart disease. N. Engl. J. Med. 2003, 349, 523-534. [CrossRef] [PubMed]

205. Wassertheil-Smoller, S.; Hendrix, S.L.; Limacher, M.; Heiss, G.; Kooperberg, C.; Baird, A.; Kotchen, T.; Curb, J.D.; Black, H.; Rossouw, J.E.; et al. Investigators, W.H.I. Effect of estrogen plus progestin on stroke in postmenopausal women: The Women's Health Initiative: A randomized trial. JAMA 2003, 289, 2673-2684. [CrossRef] [PubMed]

206. Anderson, G.L.; Limacher, M.; Assaf, A.R.; Bassford, T.; Beresford, S.A.; Black, H.; Bonds, D.; Brunner, R.; Brzyski, R.; Caan, B.; et al. Women's Health Initiative Steering, C., Effects of conjugated equine estrogen in postmenopausal women with hysterectomy: The Women's Health Initiative randomized controlled trial. JAMA 2004, 291, 1701-1712. [PubMed]

207. Engler-Chiurazzi, E.B.; Brown, C.M.; Povroznik, J.M.; Simpkins, J.W. Estrogens as neuroprotectants: Estrogenic actions in the context of cognitive aging and brain injury. Prog. Neurobiol. 2017, 157, 188-211. [CrossRef]

208. Scott, E.; Zhang, Q.G.; Wang, R.; Vadlamudi, R.; Brann, D. Estrogen neuroprotection and the critical period hypothesis. Front. Neuroendocr. 2012, 33, 85-104. [CrossRef]

209. Rocca, W.A.; Grossardt, B.R.; Shuster, L.T. Oophorectomy, estrogen, and dementia: A 2014 update. Mol. Cell Endocrinol. 2014, 389, 7-12. [CrossRef]

210. Otto, C.; Fuchs, I.; Altmann, H.; Klewer, M.; Schwarz, G.; Bohlmann, R.; Nguyen, D.; Zorn, L.; Vonk, R.; Prelle, K.; et al. In vivo characterization of estrogen receptor modulators with reduced genomic versus nongenomic activity in vitro. J. Steroid Biochem. Mol. Biol. 2008, 111, 95-100. [CrossRef]

211. Kousteni, S.; Bellido, T.; Plotkin, L.I.; O’Brien, C.A.; Bodenner, D.L.; Han, L.; Han, K.; DiGregorio, G.B.; Katzenellenbogen, J.A.; Katzenellenbogen, B.S.; et al. Nongenotropic, sex-nonspecific signaling through the estrogen or androgen receptors: Dissociation from transcriptional activity. Cell 2001, 104, 719-730. [CrossRef]

212. Koszegi, Z.; Szego, E.M.; Cheong, R.Y.; Tolod-Kemp, E.; Abraham, I.M. Postlesion estradiol treatment increases cortical cholinergic innervations via estrogen receptor-alpha dependent nonclassical estrogen signaling in vivo. Endocrinology 2011, 152, 3471-3482. [CrossRef]

213. Kwakowsky, A.; Potapov, K.; Kim, S.; Peppercorn, K.; Tate, W.P.; Abraham, I.M. Treatment of beta amyloid 1-42 (Abeta(1-42))induced basal forebrain cholinergic damage by a non-classical estrogen signaling activator in vivo. Sci. Rep. 2016, 6, 21101. [CrossRef]

214. Soltani, Z.; Khaksari, M.; Jafari, E.; Iranpour, M.; Shahrokhi, N. Is genistein neuroprotective in traumatic brain injury? Physiol. Behav. 2015, 152(Pt A), 26-31. [CrossRef]

215. Azcoitia, I.; Moreno, A.; Carrero, P.; Palacios, S.; Garcia-Segura, L.M. Neuroprotective effects of soy phytoestrogens in the rat brain. Gynecol. Endocrinol. 2006, 22, 63-69. [CrossRef] [PubMed]

216. Qian, Y.; Guan, T.; Huang, M.; Cao, L.; Li, Y.; Cheng, H.; Jin, H.; Yu, D. Neuroprotection by the soy isoflavone, genistein, via inhibition of mitochondria-dependent apoptosis pathways and reactive oxygen induced-NF-kappaB activation in a cerebral ischemia mouse model. Neurochem. Int. 2012, 60, 759-767. [CrossRef] [PubMed]

217. Wu, Y.; Zhang, X.; Li, Z.; Yan, H.; Qin, J.; Li, T. Formononetin inhibits human bladder cancer cell proliferation and invasiveness via regulation of miR-21 and PTEN. Food Funct. 2017, 8, 1061-1066. [CrossRef] [PubMed]

218. Qiu, G.; Tian, W.; Huan, M.; Chen, J.; Fu, H. Formononetin exhibits anti-hyperglycemic activity in alloxan-induced type 1 diabetic mice. Exp. Biol. Med. (Maywood) 2017, 242, 223-230. [CrossRef] [PubMed]

219. Li, Z.; Zeng, G.; Zheng, X.; Wang, W.; Ling, Y.; Tang, H.; Zhang, J. Neuroprotective effect of formononetin against TBI in rats via suppressing inflammatory reaction in cortical neurons. Biomed. Pharm. 2018, 106, 349-354. [CrossRef]

220. Ma, W.W.; Hou, C.C.; Zhou, X.; Yu, H.L.; Xi, Y.D.; Ding, J.; Zhao, X.; Xiao, R. Genistein alleviates the mitochondria-targeted DNA damage induced by beta-amyloid peptides 25-35 in C6 glioma cells. Neurochem. Res. 2013, 38, 1315-1323. [CrossRef] 
221. Lu, H.; Shi, J.X.; Zhang, D.M.; Wang, H.D.; Hang, C.H.; Chen, H.L.; Yin, H.X. Inhibition of hemolysate-induced iNOS and COX-2 expression by genistein through suppression of NF-small ka, CyrillicB activation in primary astrocytes. J. Neurol. Sci. 2009, 278, 91-95. [CrossRef]

222. Valles, S.L.; Dolz-Gaiton, P.; Gambini, J.; Borras, C.; Lloret, A.; Pallardo, F.V.; Vina, J. Estradiol or genistein prevent Alzheimer's disease-associated inflammation correlating with an increase PPAR gamma expression in cultured astrocytes. Brain Res. 2010, 1312, 138-144. [CrossRef]

223. DonCarlos, L.L.; Azcoitia, I.; Garcia-Segura, L.M. Neuroprotective actions of selective estrogen receptor modulators. Psychoneuroendocrinology 2009, 34 (Suppl. 1), S113-S122. [CrossRef]

224. Sharma, D.; Kumar, S.; Narasimhan, B. Estrogen alpha receptor antagonists for the treatment of breast cancer: A review. Chem. Cent. J. 2018, 12, 107. [CrossRef] [PubMed]

225. Lien, E.A.; Wester, K.; Lonning, P.E.; Solheim, E.; Ueland, P.M. Distribution of tamoxifen and metabolites into brain tissue and brain metastases in breast cancer patients. Br. J. Cancer 1991, 63, 641-645. [CrossRef] [PubMed]

226. Smith, C.L.; O'Malley, B.W. Coregulator function: A key to understanding tissue specificity of selective receptor modulators. Endocr. Rev. 2004, 25, 45-71. [CrossRef]

227. Tsai, Y.T.; Wang, C.C.; Leung, P.O.; Lin, K.C.; Chio, C.C.; Hu, C.Y.; Kuo, J.R. Extracellular signal-regulated kinase $1 / 2$ is involved in a tamoxifen neuroprotective effect in a lateral fluid percussion injury rat model. J. Surg. Res. 2014, 189, 106-116. [CrossRef] [PubMed]

228. Lim, S.W.; Nyam Tt, E.; Hu, C.Y.; Chio, C.C.; Wang, C.C.; Kuo, J.R. Estrogen receptor-alpha is involved in tamoxifen neuroprotective effects in a traumatic brain injury male rat model. World Neurosurg 2018, 112, e278-e287. [CrossRef]

229. Komm, B.S.; Kharode, Y.P.; Bodine, P.V.; Harris, H.A.; Miller, C.P.; Lyttle, C.R. Bazedoxifene acetate: A selective estrogen receptor modulator with improved selectivity. Endocrinology 2005, 146, 3999-4008. [CrossRef]

230. Komm, B.S.; Lyttle, C.R. Developing a SERM: Stringent preclinical selection criteria leading to an acceptable candidate (WAY140424) for clinical evaluation. Ann. N. Y. Acad. Sci. 2001, 949, 317-326. [CrossRef]

231. Lan, Y.L.; Wang, X.; Zou, Y.J.; Xing, J.S.; Lou, J.C.; Zou, S.; Ma, B.B.; Ding, Y.; Zhang, B. Bazedoxifene protects cerebral autoregulation after traumatic brain injury and attenuates impairments in blood-brain barrier damage: Involvement of antiinflammatory pathways by blocking MAPK signaling. Inflamm. Res. 2019, 68, 311-323. [CrossRef]

232. Goldstein, J.S.; Sites, C.K. Selective modulation of sex steroids. Ageing Res. Rev. 2002, 1, 17-28. [CrossRef]

233. Kloosterboer, H.J. Tibolone: A steroid with a tissue-specific mode of action. J. Steroid Biochem. Mol. Biol. 2001, 76, 231-238. [CrossRef]

234. Gonzalez-Giraldo, Y.; Forero, D.A.; Echeverria, V.; Garcia-Segura, L.M.; Barreto, G.E. Tibolone attenuates inflammatory response by palmitic acid and preserves mitochondrial membrane potential in astrocytic cells through estrogen receptor beta. Mol. Cell Endocrinol. 2019, 486, 65-78. [CrossRef] [PubMed]

235. Avila-Rodriguez, M.; Garcia-Segura, L.M.; Hidalgo-Lanussa, O.; Baez, E.; Gonzalez, J.; Barreto, G.E. Tibolone protects astrocytic cells from glucose deprivation through a mechanism involving estrogen receptor beta and the upregulation of neuroglobin expression. Mol. Cell Endocrinol. 2016, 433, 35-46. [CrossRef] [PubMed]

236. Acaz-Fonseca, E.; Avila-Rodriguez, M.; Garcia-Segura, L.M.; Barreto, G.E. Regulation of astroglia by gonadal steroid hormones under physiological and pathological conditions. Prog. Neurobiol. 2016, 144, 5-26. [CrossRef] [PubMed]

237. Crespo-Castrillo, A.; Yanguas-Casas, N.; Arevalo, M.A.; Azcoitia, I.; Barreto, G.E.; Garcia-Segura, L.M. The synthetic steroid tibolone decreases reactive gliosis and neuronal death in the cerebral cortex of female mice after a stab wound injury. Mol. Neurobiol. 2018, 55, 8651-8667. [CrossRef] [PubMed]

238. DeWitt, D.S.; Hawkins, B.E.; Dixon, C.E.; Kochanek, P.M.; Armstead, W.; Bass, C.R.; Bramlett, H.M.; Buki, A.; Dietrich, W.D.; Ferguson, A.R.; et al. Pre-clinical testing of therapies for traumatic brain injury. J. Neurotrauma 2018, 35, 2737-2754. [CrossRef] 